\title{
FGM/C decision-making process and the role of gender power relations in Sudan
}

Ahmed Gamal Eldin

Suad Babiker

Majdi Sabahelzain

Muna Eltayeb

Follow this and additional works at: https://knowledgecommons.popcouncil.org/departments_sbsr-rh

Part of the Demography, Population, and Ecology Commons, Family, Life Course, and Society Commons, Gender and Sexuality Commons, and the International Public Health Commons How does access to this work benefit you? Let us know!

\section{Recommended Citation}

Eldin, Ahmed Gamal, Suad Babiker, Majdi Sabahelzain, and Muna Eltayeb. 2018. "FGM/C decision-making process and the role of gender power relations in Sudan," Evidence to End FGM/C: Research to Help Women Thrive. New York: Population Council. 


\section{Evidence to End FGM/C}

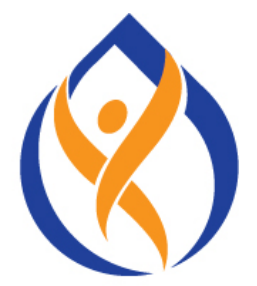

Research to Help Girls and Women Thrive

\section{FGM/C DECISION-MAKING PROCESS AND THE ROLE OF GENDER POWER RELATIONS IN SUDAN}

October 2018 
FGM/C DECISION-MAKING PROCESS AND THE ROLE OF GENDER POWER RELATIONS IN SUDAN

\author{
AHMED GAMAL ELDIN \\ SUAD BABIKER \\ MAJDI SABAHELZAIN \\ MUNA ELTAYEB
}

AHFAD UNIVERSITY FOR WOMEN

OCTOBER 2018 
The Evidence to End FGM/C: Research to Help Girls and Women Thrive generates evidence to inform and influence investments, policies, and programmes for ending female genital mutilation/cutting in different contexts. Evidence to End FGM/C is led by the Population Council, Nairobi in partnership with the Africa Coordinating Centre for the Abandonment of Female Genital Mutilation/Cutting (ACCAF), Kenya; the Global Research and Advocacy Group (GRAG), Senegal; Population Council, Nigeria; Population Council, Egypt; Population Council, Ethiopia; MannionDaniels, Ltd. (MD); Population Reference Bureau (PRB); University of California, San Diego (Dr. Gerry Mackie); and University of Washington, Seattle (Prof. Bettina Shell-Duncan).

POPULATION COUNCIL

Ideas. Evidence. Impact.

The Population Council confronts critical health and development issues-from stopping the spread of HIV to improving reproductive health and ensuring that young people lead full and productive lives. Through biomedical, social science, and public health research in 50 countries, we work with our partners to deliver solutions that lead to more effective policies, programmes, and technologies that improve lives around the world. Established in 1952 and headquartered in New York, the Council is a nongovernmental, nonprofit organisation governed by an international board of trustees. www.popcouncil.org

The Gender and Reproductive Rights Resource and Advocacy Centre (GRACe) is a leading regional center of excellence on gender and reproductive health and rights; Providing quality resources for all stakeholders, building capacities, promoting evidence-based planning and policy for empowering women and men and promoting reproductive health as a fundamental human right for all. GRACe values are gender equality, women empowerment, integrity, respect for human rights and excellence. It aims to promote gender equality and reproductive health and rights of the community in general and of women in Sudan and the region. www.grace.ahfad.edu.sd

Suggested Citation: Gamal Eldin, A, Babiker, S, Sabahelzain, M, Eltayeb, M. 2018. "FGM/C Decision-Making Process and the Role of Gender Power Relations in Sudan." Evidence to End FGM/C: Research to Help Girls and Women Thrive. New York: Population Council.

This is a working paper and represents research in progress. This paper represents the opinions of the authors and is the product of professional research. This paper has not been peer reviewed, and this version may be updated with additional analyses in subsequent publications. Contact: Dr Ahmed Gamal Eldin, ahmedeldin@outlook.com

Please address any inquiries about the Evidence to End FGM/C programme consortium to:

Dr Jacinta Muteshi, Project Director, imuteshi@popcouncil.org

Funded by:

This document is an output from a programme funded by the UK Aid from the UK government for the benefit of developing countries. However, the views expressed and information contained in it are not necessarily those of, or endorsed by the UK government, which can accept no responsibility for such views or information or for any reliance placed on them. 


\section{Table of Contents}

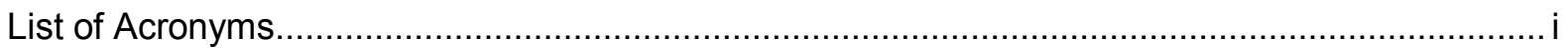

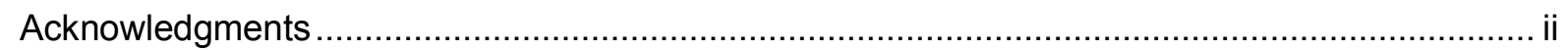

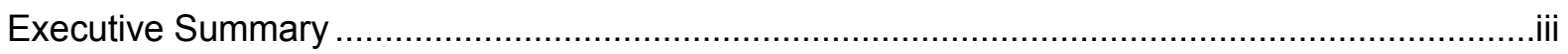

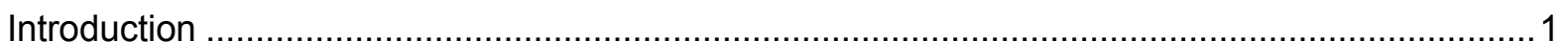

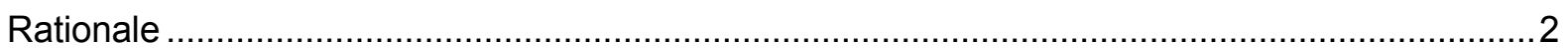

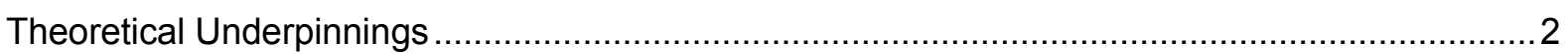

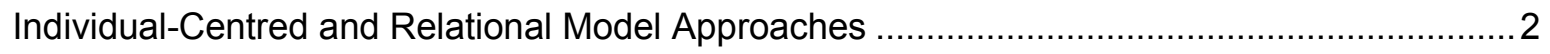

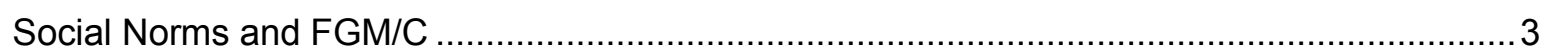

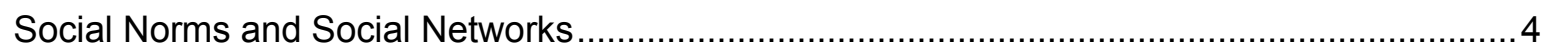

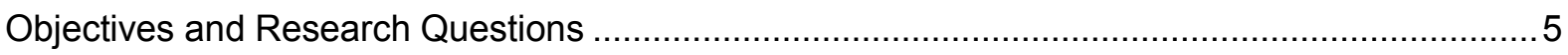

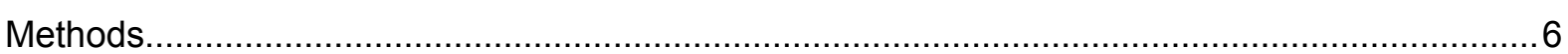

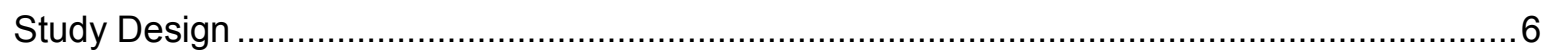

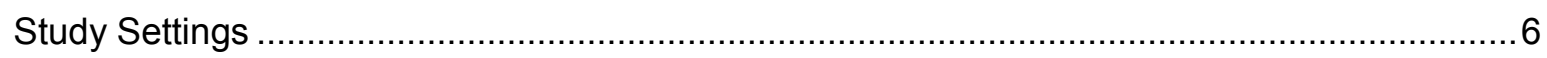

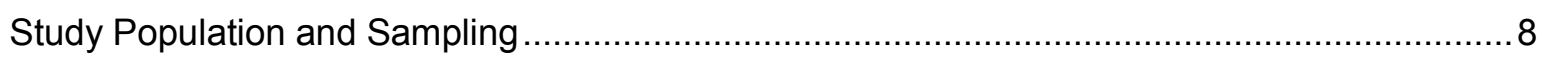

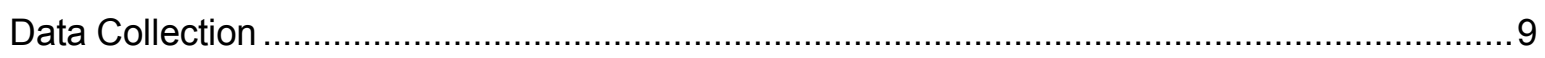

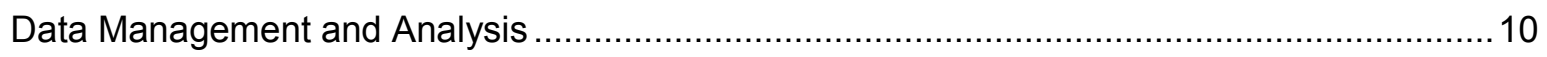

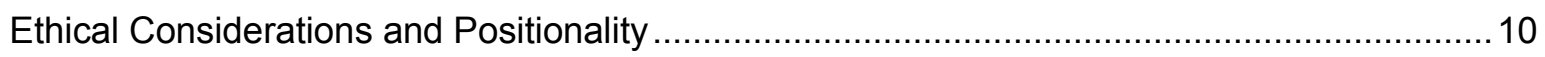

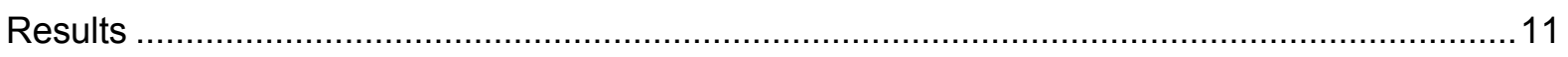

Sociodemographic Characteristics of Surveyed Households ............................................ 11

Socio-demographic Characteristics of Qualitative Interview Participants .............................. 13

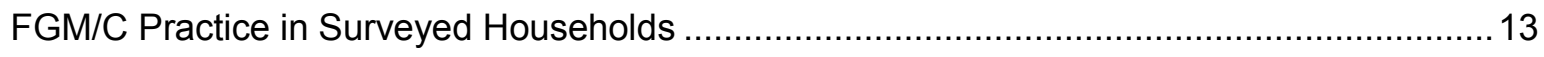

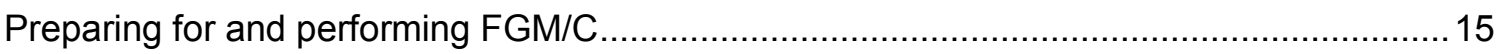

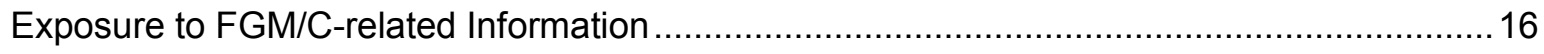

Reasons for Performing FGM/C

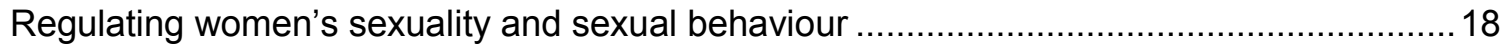

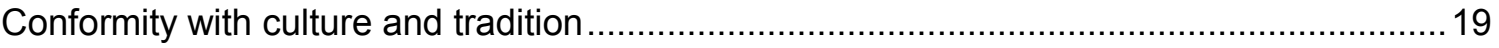

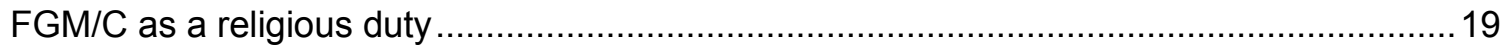

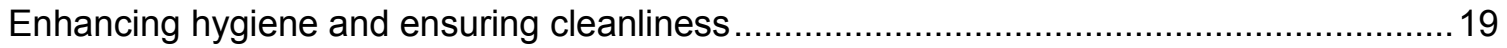

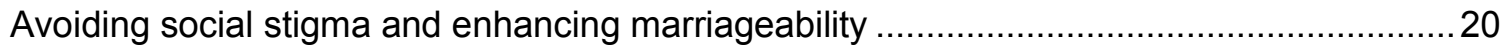

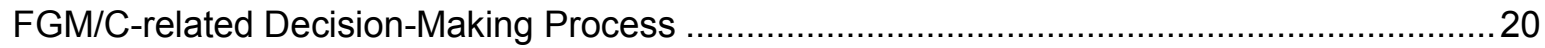

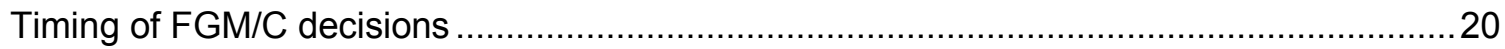

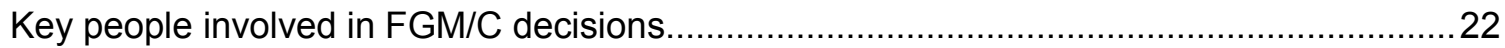

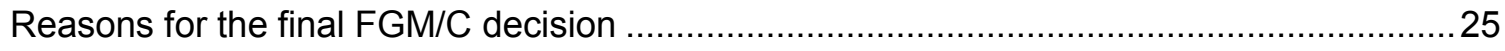




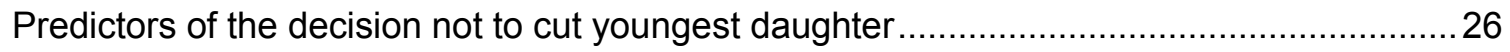

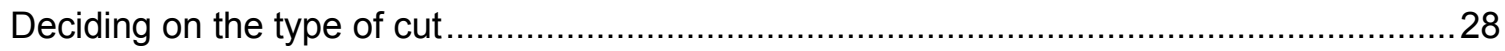

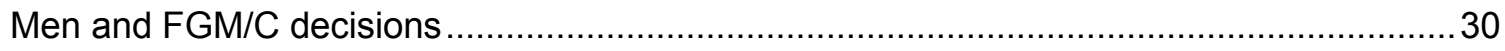

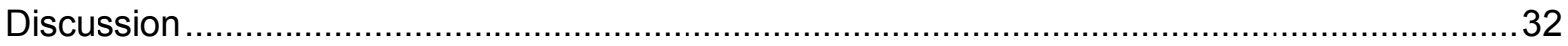

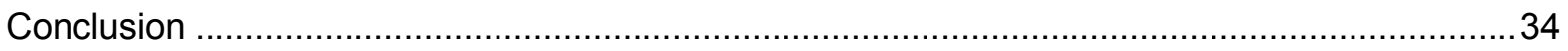

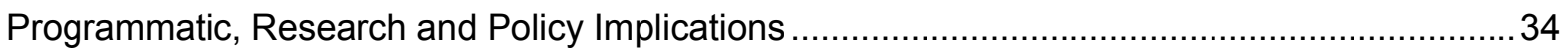

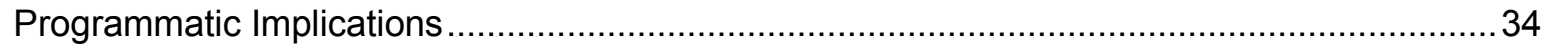

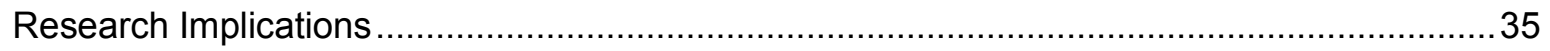

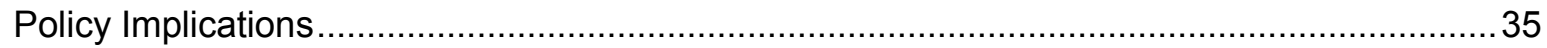

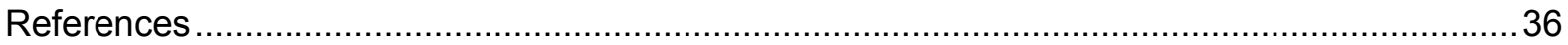




\section{List of Acronyms}

$\begin{array}{ll}\text { AUW } & \text { Ahfad University for Women } \\ \text { DFID } & \text { Department for International Development } \\ \text { FGD } & \text { Focus Group Discussion } \\ \text { FGM/C } & \text { Female Genital Mutilation/Cutting } \\ \text { GRACe } & \text { Gender and Reproductive Rights Resource and Advocacy Centre } \\ \text { IDI } & \text { In-depth Interview } \\ \text { IRB } & \text { Institutional Review Board } \\ \text { MICS } & \text { Multi-Indicator Cluster Survey } \\ \text { NCCW } & \text { National Council for Child Welfare } \\ \text { SCCW } & \text { State Council for Child Welfare } \\ \text { SFFGC } & \text { Sudan Free from Female Genital Cutting Programme } \\ \text { SHHS } & \text { Sudan Household and Health Survey } \\ \text { SPSS } & \text { Statistical Package for Social Sciences }\end{array}$




\section{Acknowledgments}

Several people have contributed, in different ways, to making this study possible. We would like first to thank the heads and all the members of the 515 households in the states of Khartoum and Gedaref who allowed us into their homes, spared valuable time and openly shared with us their views and experiences on female genital mutilation/cutting (FGM/C). The community leaders and key informants shared important perspectives on the context and valuable experiences and we would like to thank them for that.

Many government officials in the four targeted localities in Khartoum (Umbadda and Jebel Awliya) and Gedaref (Gedaref and Al-Faw) cooperated and provided necessary information and permissions and we will remain indebted to them for their help and support. In particular, the support from the staff of the National Council for Child Welfare (NCCW) in Khartoum and the State Council for Child Welfare (SCCW) in Gedaref was instrumental in facilitating our fieldwork and our links with local community leaders and organisations, and we thank them for their collaboration and support.

We would also like to express a special word of thanks and gratitude to the 12 women and men who took part in visiting households in Khartoum and Gedaref to collect survey data and who shared their observations and perspectives on the whole data collection process. Amin Dawd and his colleagues assisted us with data entry and statistical analysis and we would like to acknowledge their valuable help. Dr Rassayl Abdalla and Ms Hanadi Ibrahim played an important role during the qualitative research part of this study and we would like to acknowledge their valuable contribution and thank them for that. We would like to thank Professor Elfatih Elasmani and Dr Ezeldin Gaafar for their contributions in the qualitative data analysis.

Dr Jacinta Muteshi and her team at the Population Council in Nairobi provided important guidance and technical support at different stages of the research planning and implementation process and we would like to thank them for that. Professor Nafisa Bedri and the energetic team at GRACe availed all necessary support and encouragement throughout the lifetime of the research and for that we cannot thank them enough.

Last, but not least, this study and indeed the whole research project would never have been possible without the generous financial support from UK AID/DFID. We would like to thank them for their interest in providing sustained support to end all forms of FGM/C. 


\section{Executive Summary}

\section{Background and Rationale}

Decades of sustained efforts to end female genital mutilation/cutting (FGM/C) in Sudan have yielded very limited impact on the prevalence of the practice. Previous national surveys showed a very slight change in the prevalence of FGM/C between 2006 and 2014 among women aged 1549 years (from 89 percent in 2006 to 86.6 percent in 2014). Further, in 2014, the prevalence in rural areas was slightly higher than in urban areas (87.2 percent and 85.5 percent respectively). The prevalence varied by state; with six out of the 18 states in the country having a prevalence between 94 percent and 98 percent, the prevalence in nine other states ranging between 78 percent and 89 percent, while three states had a prevalence lower than 70 percent.

Reasons behind the slow pace of change in the practice are not well understood. This study aimed to contribute to a better understanding of FGM/C in Sudan and the way different families perceive the practice and make FGM/C-related decisions. The ultimate goal is to inform interventions aimed at accelerating the pace of positive behavioural and social norm change and eventually promote the abandonment of all forms of FGM/C in Sudan.

\section{Research Questions}

Drawing on both social norms and social network theories, we investigated whether FGM/C is an individual-based decision or a relational decision that involves multiple decision makers who are influenced by others, within and beyond the households in which the girls live. The specific questions we sought to answer were:

1. What processes do households take to reach a decision on FGM/C (including whether to cut and the type of cut)? And what are the key moments in such processes?

2. Who is involved in FGM/C-related decisions and who are the most influential individuals and what makes them influential?

3. What makes certain families or individuals of similar backgrounds different in relation to their views and attitude towards FGM/C?

4. What are the main factors that shape people's views and attitude towards FGM/C?

5. What are the main types, sources and channels from which people get their information on $\mathrm{FGM} / \mathrm{C}$ ?

6. What is the role of gender in decision-making around $\mathrm{FGM} / \mathrm{C}$, and what empowers men and women to decide to abandon FGM/C?

7. What are the most important context factors that affect decisions on FGM/C, including decisions on the type of cut (level of severity)?

\section{Methods}

We conducted a cross-sectional, mixed methods study combining qualitative methods (focus group discussions [FGDs] and in-depth interviews [IDIs]) and quantitative (household survey) measures. The study was carried out in urban and rural areas in Khartoum and Gedaref States. These states were selected because they reflect typical social groups in Sudan and represent a level of diversity in terms of severity of FGM/C, socio-cultural and economic backgrounds and exposure to FGM/C campaign and materials. This diversity enabled us to understand the factors associated with the decision-making process regarding abandoning, shifting or practising $\mathrm{FGM} / \mathrm{C}$ at both the regional and national levels. Four localities were selected; two from each state. These localities were selected from a list generated by the Sudan Free from Female Genital Cutting (SFFGC) 
Programme, a five-year initiative funded by the UK Government to promote FGM/C abandonment in Sudan.

We first conducted the household survey to assess the role of gender in families' decisions to abandon or practise $\mathrm{FGM} / \mathrm{C}$. We then conducted the qualitative interviews to better understand the complexities around FGM/C decision-making. The household survey sample included 515 households (Khartoum $n=314$ and Gedaref $n=201$ ). Fifteen FGDs were held; eight with groups of women and seven with men of different age and socioeconomic and ethnic backgrounds. We also conducted 18 IDIs with key informants including religious and community leaders. Qualitative interviews were held in the same localities as the household survey.

\section{Findings and Discussion}

\section{Current trends in FGM/C}

- $\mathrm{FGM} / \mathrm{C}$ is widely practised in the research sites. Forty-seven percent of young women and girls aged 0 to 19 years in surveyed households had been cut. Girls are reportedly cut just before or after they start attending school (five-nine years). According to some qualitative interview participants girls were most likely to be cut during school holidays and religious festivals because these are occasions when there are extended family gatherings and annual visits to the grandparents and other relatives.

- There is a shift in the type of cut, with the longstanding pharaonic (infibulation/type III FGM/C) becoming widely abandoned and replaced by the so-called "sunna"type. Of the girls who had been subjected to $\mathrm{FGM} / \mathrm{C}, 74$ percent were reported to have undergone the "sunna" cut. The most common reason given for decisions on the type of cut was that it was less severe.

- There is evidence of increasing medicalisation of FGM/C. Seventy percent of girls and young women had been circumcised by health care providers including trained midwives.

- Sociocultural factors, gender norms and power relations drive the continuation of FGM/C. Survey data indicate that just over half (52 percent) of those who decided to circumcise viewed it as a cultural practice, a third (33 percent) considered it a religious duty, just over a quarter (26 percent) believed it is necessary for chastity, 16 percent said it was important for marriageability, and 13 percent said it was important for health reasons. Justifications of FGM/C centred on the need to reduce women's sexual desire.

- Participants were aware of the health consequences of FGM/C for women and girls. Awareness of the harms was linked to a shift from the 'severe' pharaonic to the "sunna" cut, which was perceived to be 'less harmful' or 'not harmful'. The majority ( 57 percent) of those who decided not to cut cited health reasons.

\section{Decision-making process}

- Families go through lengthy and complex deliberations involving nuclear and extended family members and other influencers. The matters under consideration in these discussions include whether to circumcise girls or not and the type of cut. The discussions were reported to begin when girls are aged between three and nine years and were often initiated by the girl's mother or grandmother. The discussions were noted to involve both men and women from the nuclear and extended families. Non-family members, such as friends, neighbours and midwives, were also reported to participate in FGM/C-related decisions.

- In terms of improving focus and targeting intervention to end FGM/C, the key moments in the decision-making process are the time (and age) when the deliberation on FGM/C are initiated and the time of the year/season (and age) when the procedure is undertaken. . 
- Mothers are key decision makers. In almost three-quarters of the cases, mothers were reported to have made the decision. Nevertheless, women do not make decisions in isolation, and there are often many other decision makers within and beyond their household. Decisions are also reportedly influenced by concerns about sanctions from other members of their reference group.

- Mothers' individual experiences influence their decisions. A final decision to cut a girl was more likely when her mother was circumcised.

- Health professionals are involved in FGM/C decisions. About one in ten respondents noted that health professionals were influential in FGM/C-related decisions.

- Legal restrictions may influence families' decisions. Respondents who lived in Gedaref State, which has a state law banning FGM/C, were approximately twice as likely to decide not to circumcise their girl as those who lived in Khartoum State, which has no law.

\section{Gender and inter-generational power relations}

- Men are involved and influential in FGM/C decisions. Although some men were noted to be indirectly involved, study findings indicate that husbands were often involved and influential, particularly when they were opposed to having their daughters circumcised.

- Men, especially young men, hold contradictory positions on FGM/C. Although some young men expressed a willingness to marry uncut women, citing greater sexual responsiveness, they worried that excessive sexual desire can be risky or dangerous for women. As a result, some of these young men stated that they would marry an uncut girl but would prefer for their own sister to be cut.

- Maternal and paternal grandmothers are important actors in FGMC decision-making, with paternal grandmothers influencing their sons (girls' fathers) and maternal grandmothers influencing their daughters (girls' mothers).

\section{Conclusion}

Although parents often make the final decision to cut or not cut their daughters, they do not act in isolation but are influenced by dominant social norms and by other family members who are also influenced by other people and factors and norms. In general, the widespread support and practise of FGM/C in the research area is perpetuated and sustained by deeply rooted social norms and gender power structures that centre on the need to reduce women's sexual desire in order to protect them.

\section{Programmatic, Research and Policy Implications}

\section{Programmatic Implications}

- The observed increase in the medicalisation of FGM/C and the "sunna" cut are both a threat and an opportunity for full abandonment efforts. These shifts may be an opportunity for further shifts and changes towards the abandonment of all forms of FGM/C. The involvement of medical cadres may also provide a chance to influence the spread of the practice through health regulations or legal reforms. At the same time, the belief that the "sunna" cut performed by trained medical staff addresses the harms arising from FGM/C may pose a huge challenge for abandonment efforts. FGM/C plans and programmes at all levels must therefore respond to the medicalisation of FGM/C and the shift to "sunna" cutting.

- The study findings underscore the need for interventions that address gendered social norms that support the regulation of women's sexuality and sexual behaviour. Programmes should 
incorporate sexual and reproductive health education targeted towards men and women of different ages.

- Important moments in the decision-making process are the time (and age) when deliberations on FGM/C are initiated and the time of the year/season (and age) when girls are typically circumcised. These key moments present windows for intensive campaigns and programmatic interventions.

- Men are directly and indirectly involved in FGM/C decisions. Men-both young and old-must therefore be targeted in FGM/C programmes. Further, their views and positions on FGM/C must be understood and integrated in efforts to address abandonment.

\section{Research Implications}

Study findings highlight several important research gaps:

- While many participants who still practise FGM/C claim that girls undergo the "sunna" cut, little is known about what the "sunna" cut means, its religious underpinnings, and the implications of this shift on efforts to abandon all types of FGM/C. Further research on this shift is warranted.

- Gender and social norms about women's sexual behaviour and sexuality are significant, but not well understood. Further research is needed to how these norms intersect with religious norms to sustain $\mathrm{FGM} / \mathrm{C}$.

- Increased migration and access to mass media may influence people's reference groups and social networks. Further research is needed to understand the nature of social networks in increasingly complex contexts.

- Fathers were noted to be very influential especially in instances where they were opposed to having their daughters circumcised. Similarly, some young men reported contradictory views about FGM/C noting their willingness to marry uncut women, while supporting FGM/C for their own sisters. Further research is needed to understand men's views and attitudes towards FGM/C. A better understanding of their views and attitudes may inform the development of programmes targeted to men.

\section{Policy Implications}

- Study findings suggest that legal restrictions may promote the abandonment of FGM/C or drive shifts in the practice. These results suggest the need for investments in research to understand how laws can be strengthened to promote the abandonment of all forms of FGM/C. 


\section{Introduction}

Four decades of efforts to end female genital mutilation/cutting (FGM/C) in Sudan have yielded limited results. Between 2006 and 2014, the prevalence of FGM/C among women aged 15-49 years across the country showed little change-89 percent in 2006 and 86.6 percent in 2014 (Central Bureau of Statistics [CBS] and UNICEF Sudan 2016). The most recent Multi-Indicator Cluster Survey (MICS, 2014) results also showed slight difference between the prevalence in the rural and urban areas (87.2 percent and 85.5 percent respectively) (CBS and UNICEF Sudan 2016). Secondary analysis of the 2014 MICS indicates that prevalence varied across the country (Figure 1); with six out of the 18 states in the country having a prevalence between 94 percent and 98 percent, the prevalence in nine other states ranged between 78 percent and 89 percent, while three states had prevalence lower than 70 percent. Central Darfur had the lowest prevalence recorded as 45 percent (CBS and UNICEF Sudan 2016).

Figure 1. FGM/C prevalence among women aged 15-49 years in Sudan.

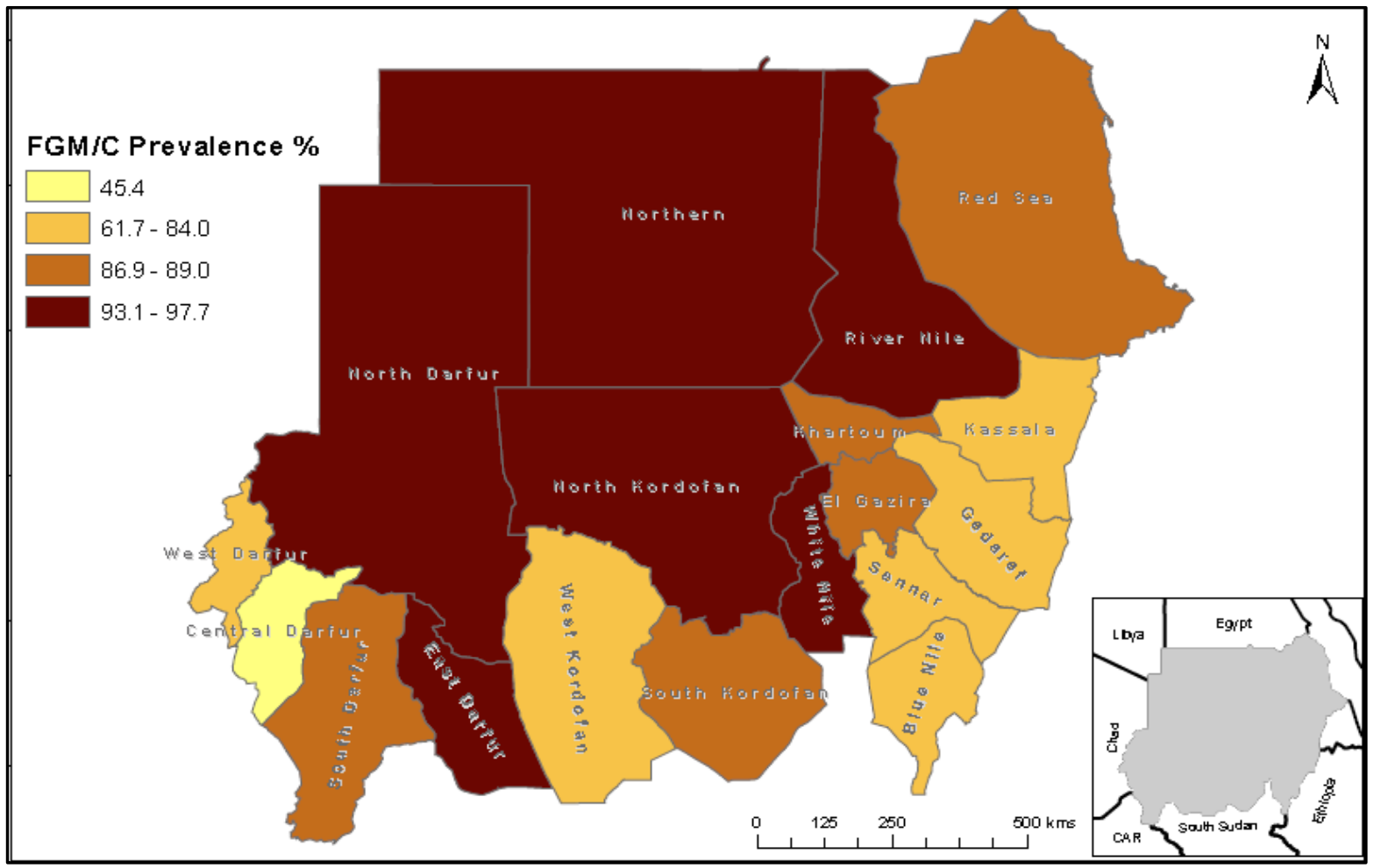

Source: MICS, 2014

Although the national prevalence was high, the 2014 MICS results indicated that there were shifts in the practice. For example, the national prevalence among young girls (0-14 years) was only 31.5 percent. Further, 52.8 percent of women aged 15-49 years supported the abandonment of the practice (CBS and UNICEF Sudan 2016). While the proportion of rural women who supported abandonment mirrored the national average, 67.3 percent of urban women supported abandonment. Differences in the prevalence of FGM/C across different age cohorts also suggests a decline in the practice with a lower proportion of younger age groups having been cut. However, many young girls in many parts of the country, including the two states that are targeted by this study (Khartoum and Gedaref), still face the risk of being cut. 


\section{Rationale}

The shifting, complex picture of $F G M / C$ in different parts of the country is challenging to understand. If it is well understood and integrated into anti-FGM/C campaigns and programmes, we can accelerate positive change and promote abandonment. Results from the 2000, 2006 and 2010 Sudan Household and Health Surveys (SHHS) and 2014 MICS suggest that although FGM/C continues to be practised by most Sudanese families, there are noticeable shifts in the practice and families seem to be divided about whether to continue or stop the practice (CBS and UNICEF Sudan 2016; SHHS 2006, 2010). The reasons behind these shifts are not well understood. Yet, the shift in attitudes and practices suggest that decision-making around FGM/C is complex, lengthy and indeed contestable due to differences in individual, family and community level views about the practice.

A study conducted in two areas of Khartoum in 2014 revealed some of these complexities and showed that many individuals, not only within nuclear and extended families, but also beyond them, such as friends, work colleagues, religious figures and local activists, are involved in such decisions (Gamal Eldin \& Hussein 2014). The study also showed that some family members were more influential than others and that there was a complex web of social, religious, cultural, economic and political factors and experiences that shaped and influenced individual and family views and attitudes towards FGM/C. The same study found that families of the same educational, socioeconomic and cultural backgrounds and experiences tend to take different positions on FGM/C. Further, gender power relations, women's position within their household and the role they play shaped different decisions on supporting or abandoning $\mathrm{FGM} / \mathrm{C}$.

Previous studies suggest that a deeper understanding of the processes through which families discuss and decide on FGM/C, as well as the social networks, key moments and influential individuals and factors (including gender and context) that influence decisions around FGM/C can inform the design of targeted interventions that can produce quick and sustainable results in FGM/C abandonment efforts (Shell-Duncan et al 2010). In other words, if we understand how change happens; then we can make it happen faster and more sustainably.

\section{Theoretical Underpinnings}

To understand the processes through which families decide to practise or abandon FGM/C and the factors and individuals within the social networks of decision makers who influence FGM/C decisions, we drew on both social norms and social network theories. We investigated whether $\mathrm{FGM} / \mathrm{C}$ is an individual-based decision or a relational decision that involves multiple decision makers who are influenced by others, within and beyond the households in which the girl lives. These influencers can be broadly referred to as members of the decision makers' reference group. The following section summarises some of the main theoretical debates from which the study drew.

\section{Individual-Centred and Relational Model Approaches}

A significant body of academic research has focused on the development of theoretical models of behaviour change that may provide insights on the dynamics of change in FGM/C. These models fall broadly under two main paradigms: 1 ) individual-centred models, and 2) relational models that account for the influence of interactions with others within social networks. Most individual-centred models of behaviour rest on the assumption that there is a direct link between an individual's knowledge of the consequences of their behaviour and the intention to perform the behaviour (Mumtaz and Salway 2009). Additionally, they posit direct links between preference, intention and actual behaviour, assuming that individuals are autonomous decision makers. 
Critiques of individually-oriented models rest on the models' assumption of a direct link between an individual's intention and behaviour, and thus, programmes based on these models narrowly target mothers, who are assumed to be the primary decision makers regarding circumcision of their daughters (Yoder 2001; Shell-Duncan and Hernlund 2006). Within the field of health behaviour, this orientation has been dubbed the "individualist fallacy"- -that is, incorrectly assuming that individuals can and do have control over their own behaviour, while overlooking the social context in which decisions are made (Davies 1992).

Instead, research on $\mathrm{FGM} / \mathrm{C}$ reveals that mothers rarely make decisions in isolation and highlights the importance of understanding the interactions of decision makers and the context in which decisions are made (Shell-Duncan and Hernlund 2006). Echoing the decision-making scenario found to surround FGM/C (Shell-Duncan and Hernlund 2006; Shell-Duncan et al. 2011), Aubel (2011) argues that in many non-Western societies, decisions, not only about FGM/C but more broadly regarding child health and nutrition issues, are rarely made independently by young mothers. Instead, Aubel's extensive literature review reveals that throughout non-Western collectivist societies, extended families are more prevalent and provide multigenerational childcare systems. She finds that childcare networks are typically organised along lines of age and gender, and that age, social status and the experience of network members determines their degree of influence in decision-making concerning childcare (Aubel 2011). This implies that interventions on child health, including those on FGM/C, should broaden their focus beyond individual mothers and target the multiple, interconnected members of childcare networks. The focus on mothers is shaped by a misperception that mothers are the main (and independent) decision makers on such issues.

\section{Social Norms and FGM/C}

The origins of $\mathrm{FGM} / \mathrm{C}$ and the drivers behind its continuation have been a matter of debate for many scholars, as well as an issue of contestation and disagreement among them. Some argue that FGM/C is practised and persists because some societies believe that it controls sexual fidelity in contexts marked by resource inequality and polygamy (Mackie and LeJeune 2009). Different societies have diverse sexuality-control practices. For example, Mackie and LeJeune (1996) noted that foot binding in China was widely practised to enforce chastity and fidelity by limiting women's physical mobility, while in Southwest Asia, women are secluded or required to dress very modestly for the same reasons. In many African societies, FGM/C is practised to suppress female sexual desire, control their sexual behaviour, and increase their marriageability (Berg and Denison 2013). These fidelity-control practices are enforced by "widespread social sanctions and internalised conscience" (Mackie and LeJeune 2009, p. 3).

According to Mackie (2000), marriageability is especially important for females because it is a means to secure long term financial stability because of the socioeconomic conditions of women. According to social norm theory, tradition and marriageability are closely related. Marriageability is often cited as a reason why families continue to practise FGM/C in countries of low and high prevalence (Mackie and LeJeune 2009). Mackie (2000) also argues that peer pressure can be another potential independent source for sustaining the practice. Additionally, in some cultural settings, FGM/C can be associated with other factors, such as religion (Berg and Denison 2013). As such, a practice that arose as a marriage convention may be further enforced through a variety of social, moral or religious norms (Mackie and LeJeune 2009).

Patriarchy and gendered power relations that oppress women play an important role in the continuation of FGM/C. Mackie and LeJeune (2009) argue that FGM/C is influenced by male domination and sustained by inequalities between men and women. According to them, the practice stems from an extreme form of patriarchy-imperial polygyny, where elite males demand 
the fidelity of their concubines or multiple wives-and the link to marriageability may sustain the practice even when originating conditions no longer exist (Mackie and LeJeune 2009: 05).

Scholars such as Mackie (1996) assert that the adoption, continuation and abandonment of FGM/C can be explained using the social convention model. Families carry out FGM/C to ensure the marriageability and status of their daughters within the intermarrying group. Within such conceptualisation, what one family chooses to do depends largely on what other families in that community choose to do. No one family has an incentive to deviate: if they do, their daughter is destined to not be married or to have a poor marriage. The social convention model thus assumes that abandonment can only be achieved when everyone in the intermarrying community gives it up (Mackie 1996).

Testing the assertions of the social convention approach, Efferson et al (2015) studied FGM/C in the Gezira Region of Central Sudan and found that "marriage pools did not typically divide or fragment communities based on cutting practices" (p. 1447). They further asserted that theoretical analysis showed that coordination did not explain the variation observed in cutting rates even if one allowed for multiple marriage pools within communities. Efferson et al (2015) thus concluded that FGM/C is not a social coordination norm. These findings have been challenged by Mackie (2017) who pointed out several analytical and methodological flaws in their study. Mackie also pointed out that research evidence from around Africa strongly support the association of FGM/C with marriageability and indicated that the practice is sustained by interdependent beliefs and actions within an intra-marrying community; asserting that $F G M / C$ is indeed a social convention, or social norm of coordination (Mackie 2017).

Other scholars have also questioned and interrogated some of the assertions made by proponents of the social convention approach. For example, Shell-Duncan and colleagues (2011) tested the predictions of social convention theory in a study conducted in Senegal and The Gambia. They found no support predictions based on the theory. Specifically, they found that participants did not agree that FGM/C was necessary for a girl to find a "good" husband. Further, none asserted that FGM/C was an avenue to get a richer or better husband. When participants stated that FGM/C was important or necessary for a good marriage, it was often not because they thought that men would refuse to marry uncircumcised women, but because they believed that an uncircumcised woman marrying into a circumcising family would face difficult relationships with other women in her marital home (Shell-Duncan et al. 2011). Tradition, rather than marriageability, was cited as a reason for continuation in some communities. Shell-Duncan et al (2011) therefore concluded that FGM/C can be held in place by several social conventions and norms that vary across time and context. According to these scholars, individuals suffer shame and exclusion for failing to conform to social expectations regarding proper behaviour. Consequently, individuals who come to support abandonment of FGM/C often cannot act upon this preference unless members of their family and their extended social community agree (Shell-Duncan, et al, 2011).

\section{Social Norms and Social Networks}

Researchers interested in behavioural change are increasingly focusing on how individuals' views and attitudes depend on their social ecology. In the health field, individual-based health theories are being enriched by ecological models of health behaviour that consider the complex layers of reciprocal influences between individuals and their environment (Cislaghi and Heise 2018). One of the most powerful and all-encompassing environmental influences is the social network in which the person is embedded (Shell-Duncan et al 2011).

While recognising the importance of social conventions, Shell-Duncan et al (2011) underscore the importance of also considering the social network within which individuals interact. Thus, interventions that focus on individuals without also reaching out to their social networks will not be 
effective in mitigating social sanctions and stigma from failing to conform (Shell-Duncan et al 2011). Coordination among members of extended networks is, therefore, imperative for the occurrence of greater change and wider abandonment of FGM/C.

A social network approach characterises the web of social relations around an individual. The simplest form of a network is a social dyad (e.g., two spouses, two siblings, two friends, two neighbours). However, a network can be expanded to any size as long as meaningful ties among the included individuals can be reliably measured.

In this study, we interrogated the social norms that sustained and provided justifications for the continuation of FGM/C, despite widespread knowledge of its harmful impact on women and girls. We considered the possible influence of others in the wider social network that includes extended families, friends and neighbours, health care providers and religious figures. In doing so, rather than simply focusing on girls' parents as 'autonomous' decision makers, we examined the broader social networks and reference groups that shape or influence their decisions. We also assessed the role of gender power relations in influencing, shaping and/or sustaining social norms and individuals' attitude towards FGM/C.

\section{Objectives and Research Questions}

The overall aim of this study was to understand FGM/C decision-making and the role of gender relations in the FGM/C decision-making process across differing contexts in Sudan with the goal of informing the design of gendered approaches to FGM/C abandonment. Specifically, we sought to explore and understand how different parents and families reach a decision on FGM/C and the individuals and factors that influence them in doing so. Further, we explored, examined and mapped the social networks that influenced or shaped these decisions, and the background characteristics of the closest/most influential persons in such social networks.

The main questions we sought to answer were:

1. What processes do households take to reach a decision on FGM/C (including whether to cut and the type of cut)? And what are the key moments in such processes?

2. Who is involved in FGM/C-related decisions and who are the most influential individuals and what makes them influential?

3. What factors and determinants contribute to families or individuals of similar background making different decisions concerning FGM/C?

4. What are the main factors that shape female and male views and attitudes towards $\mathrm{FGM} / \mathrm{C}$ ?

5. What are the main types, sources and channels from which females and males get their information on $\mathrm{FGM} / \mathrm{C}$ ?

6. What is the role of gender in decision-making around FGM/C, and what empowers men and women to decide to abandon FGM/C?

7. What are the most important context factors that affect decisions on FGM/C, including decisions on the type of cut (level of severity)?

The design and approach of the study is informed by the following five main hypotheses:

1. Within a context of shifting views and attitudes towards FGM/C, families get engaged in a process of deliberation and discussions before reaching a final decision on the practice. 
2. $\mathrm{FGM} / \mathrm{C}$ decision-making rarely happens in isolation. Instead, there are multiple decision makers who are each, in turn, influenced by other members of their social networks.

3. Members of a social network who are more proximate (i.e. extended family) will have greater influence on decision-making that those who are less proximate, regardless of their standing in the community (religious leaders, health professionals, NGO leaders).

4. Prevalence of $F G M / C$ will be higher in rural than urban communities. The prevalence of $\mathrm{FGM} / \mathrm{C}$ among mothers in the community, as an indicator of pressure to conform to norms regarding $\mathrm{FGM} / \mathrm{C}$, will be a significant predictor of girl's $\mathrm{FGM} / \mathrm{C}$ status, independent of the FGM/C status of her own mother.

5. Marriageability may be a key norm driving the perpetuation of FGM/C, yet the practice is also perpetuated by other social, moral and religious norms including gender norms.

\section{Methods}

\section{Study Design}

Given the nature of the research questions, we conducted a cross-sectional, mixed methods study combining qualitative methods (focus group discussions [FGDs] and in-depth interviews [IDIs]) and quantitative (household survey) approaches. The rationale behind using these mixed methods was firstly to estimate and to quantify the role of gender in decision-making processes regarding $\mathrm{FGM} / \mathrm{C}$ abandoning, shifting or practising and secondly to better understand the complexities around FGM/C decision-making and the role of gender on decision-making. We first conducted a household survey to assess the role of gender in families' decisions to abandon or practise FGM/C. We then conducted the qualitative interviews that were informed by the results of the survey and to get in-depth knowledge about the complex issues that emerged from the results of the survey; focus group discussions and in-depth interviews were used.

The study was conducted in four main phases that were carefully sequenced. The first phase involved a critical review of the FGM/C literature, focusing on Sudan and Africa. The review helped the research team understand the general situation, existing knowledge and gaps and challenges facing researchers and practitioners. The review also helped position the research, avoid duplications and informed the selection and design of the study and data collection tools. In the second phase, we conducted a household survey in the study sites (described in the following subsection). The survey was necessary given the very limited information about FGM/C in the research area because it provided quantitative data on FGM/C attitude and practices. The survey also informed the design of, and selection of participants for, the qualitative interviews. The third phase focused on the collection and analysis of qualitative data through IDIs with key informants and FGDs with men and women in the study sites. Tools for the qualitative interviews and discussions were informed by the initial findings of the household survey. The fourth phase was devoted to data analysis, report writing and dissemination of findings.

\section{Study Settings}

This study was conducted in urban and rural areas in Khartoum and Gedaref States in Sudan. These states were selected because they reflect typical social groups in Sudan and represent a level of diversity in terms of severity of $\mathrm{FGM} / \mathrm{C}$, socio-cultural and economic backgrounds and exposure to $\mathrm{FGM} / \mathrm{C}$ campaign and materials. This diversity enabled us to understand the factors associated with the decision-making process regarding abandoning, shifting or practising $\mathrm{FGM} / \mathrm{C}$. FGM/C-related indicators for the two states are summarised in Table 1. 
Table 1. FGM/C-related indicators in Khartoum and Gedaref States.

\begin{tabular}{|c|c|c|}
\hline Indicators & Khartoum State & Gedaref State \\
\hline FGM/C prevalence & $87.5 \%$ & $78.5 \%$ \\
\hline $\begin{array}{l}\text { Women (15-49 years old) who had a 'sewn closed' } \\
\text { form of FGM/C }\end{array}$ & $71.3 \%$ & $74.6 \%$ \\
\hline $\begin{array}{l}\text { Women ( } 15-49 \text { years old) who had 'flesh removed' } \\
\text { form of FGM/C }\end{array}$ & $22.1 \%$ & $9.7 \%$ \\
\hline $\begin{array}{l}\text { Daughters aged ( } 0-14 \text { years old) who had any form of } \\
\text { FGM/C }\end{array}$ & $29.9 \%$ & $28.9 \%$ \\
\hline Women (15-24 years old) who are literate & $82.6 \%$ & $42.8 \%$ \\
\hline $\begin{array}{l}\text { Women ( } 20-49 \text { years old) who first married or entered } \\
\text { a marital union before their } 18 \text { th birthday }\end{array}$ & $27.0 \%$ & $49.0 \%$ \\
\hline
\end{tabular}

Khartoum State covers an area of $22,122 \mathrm{~km}^{2}$ and in 2018 is projected to have a population of approximately 7.4 million people (Central Bureau of Statistic ND; Saeed, Weng, Mohamed and Mohammed 2014). Geographically, Khartoum State is divided into three clusters: Khartoum, Khartoum North and Omdurman. The Khartoum cluster is administratively subdivided into two localities: Khartoum and Jebel Awliya. Khartoum North comprises of the Khartoum North and Nile East localities. Omdurman comprises three localities, namely, Omdurman, Umbadda and Karari. Omdurman is the largest town in this cluster and is known as the historical capital of Sudan. Khartoum city is the political capital of Sudan where offices of the state, governmental institutions, ministries, embassies and international and regional organisations are located. In 2014, FGM/C prevalence in the state was estimated at 87.5 percent (Figure 1), while the prevalence of FGM/C among girls aged 0-14 years was 29.9 percent (CBS and UNICEF Sudan 2016). Khartoum does not have an anti-FGM/C law.

Gedaref State borders Ethiopia (Figure 1). The state covers an area of approximately $71,621 \mathrm{~km}^{2}$ and comprises seven localities with a population of about two million people, projected from the fifth population census (CBS 2009). FGM/C prevalence in 2016 was estimated at 78.5 percent in the state, while the prevalence of FGM/C among girls aged 0-14 years was 28.9 percent (CBS and UNICEF Sudan 2016). Gedaref is home to the largest commercial mechanised farming schemes in Sudan and, consequently, attracts many labour migrants, refugees and internally displaced persons. Many of the migrants have settled permanently in the state. The long history of migration and settlement in the state has made it one of the most ethnically, socio-culturally and economically diverse state in the country. While some of these ethnic groups have practised FGM/C for a long time, for others the practice has largely been adopted as a result of migration and socio-cultural interaction with other groups, especially in urban and semi-urban areas. While there is no federal law that bans FGM/C in Sudan, Gedaref is one of four states that have introduced legislation that makes FGM/C illegal.

Due to budgetary and time limitations it was not possible to cover all areas of the selected states. Four localities were selected as areas of focus for the study: Jebel Awliya and Umbadda localities were selected in Khartoum State and Gedaref and Al-Faw localities were selected in Gedaref state. The two localities in each of the two states were selected as they largely reflect the wide ethnic socio-cultural and economic diversities in the selected state. The selected localities also reflect the 
different levels of interventions regarding the practice, prevalence and shift in attitudes and practices.

The selection was also informed by discussions with researchers working on other studies in Sudan within the broader research programme. We also had discussions on the selection with stakeholders and partners at both federal and state level, including those involved in the implementation of the UN Joint Programme on FGM/C and the Sudan Free from Female Genital Cutting (SFFGC) Programme, which is a five-year initiative funded by the UK Government to promote FGM/C abandonment in Sudan. The selected localities were in the focus localities for the SFFGC and the UN Joint Programme.

\section{Study Population and Sampling}

The quantitative survey was conducted in households in the four selected localities. Households were eligible for the survey if they had at least one female aged 7 years or older. The minimum sample size was computed using the following formula (Daniel 1999):

$$
\left[n=\frac{z^{2} p q}{d^{2}}\right]
$$

Where,

$\mathrm{n}=$ sample size

$z=(1-\alpha)$, is the $z$-score corresponding to a $95 \%$ confidence interval and was computed as 1.96 (rounded up to 2 )

$p=$ expected probability of FGM/C among women aged 15-49 years and was estimated at 87 percent based on the 2014 MICS (CBS and UNICEF Sudan, 2016).

$q=$ the complementary value of $p$ which is $(1-p)=13$ percent

$d=$ desired margin of error or 0.03

A minimum sample size of 502 households was determined by using this formula. Data were collected from 515 households (314 households in Khartoum and 201 in Gedaref States). The number of households sampled in each state was determined based on the population density in each state. Households were sampled using a stratified multistage cluster procedure, which helped in capturing the social groups, level of diversity in terms of severity of FGM/C, socio-cultural and socio-economic backgrounds and exposure to FGM/C campaign and materials. In the first stage, two localities in each state from the SFFGC implementation areas were randomly selected. The two localities were then stratified into rural and urban areas. In the next stage, one cluster was selected randomly from each stratum. The households were selected from each cluster using systematic random sampling by dividing the number of households in each cluster by the sample size for that cluster.

For the qualitative element of the research, we conducted 15 FGDs (eight among women and seven among men) in the same areas that the survey was undertaken, namely in Khartoum and Gedaref States. Four FGDs were conducted in each locality (i.e. two FGDs in each rural and urban area). The number of participants in each group ranged from five to eight. One FGD with men was not conducted in Al-Faw because some participants were hesitant to talk about FGM/C publicly. In addition, we conducted 18 IDIs with key informants (eight men and ten women), with at least one man and one woman from each locality. Key informants were identified during the survey by the field supervisors. 


\section{Data Collection}

For the household survey, the head of the household was informed about the study, and then he/ she was invited to participate in the survey or to nominate someone within the households to answer the survey's questions. Those who accepted to take part, were requested to complete the questionnaire themselves or nominate any adult member of their household to do so. The person who eventually completed the questionnaire was asked to read and sign the written consent form. The relationship of the respondent to the household head is summarised in Table 2.

Table 2. Relationship of the survey respondent to the head of household $(\mathrm{N}=515)$.

\begin{tabular}{lcc} 
Relationship & $(\mathbf{n})$ & Percent \\
\hline Wife & $(270)$ & 52.4 \\
Head of household & $(120)$ & 23.3 \\
Daughter & $(68)$ & 13.2 \\
Son & $(41)$ & 8.0 \\
Other & $(16)$ & 3.1 \\
\hline
\end{tabular}

Although the survey was administered to women in the majority of the households, in most cases (82 percent of households), other male and female members of the household were also present during the interview. Figure 2 shows the other household members present during the completion of the questionnaire. Wives were present in 42 percent of the interviews, daughters in 35 percent, sons in 28 percent, and husbands in 19 percent.

Figure 2. Household members present during interview.

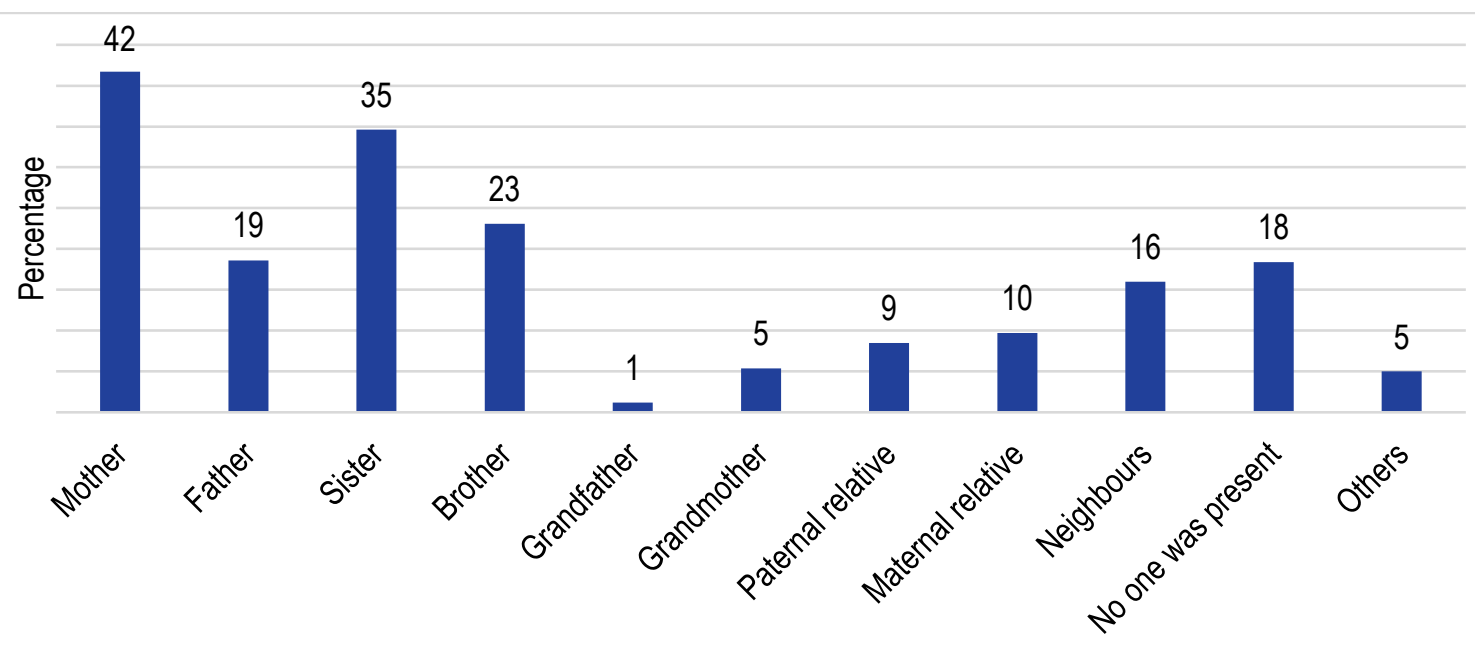

Categories given in relation to the youngest girl in the house

Quantitative data were collected using a pre-tested, structured, paper-based questionnaire. The questionnaire elicited information on the household composition, socio-demographic characteristics of household members, household socioeconomic status, exposure to FGM/C information, attitudes towards FGM/C, household decision-making around FGM/C, and the practise of FGM/C. In each household, one household member was interviewed. 
Participants for the FGDs were identified and recruited with support from local community organisations, local leaders and activists. For both men and women groups, the participants had to be aged 18 years and older. We also sought to have a mix between married and unmarried men and women. The researchers identified the key informants for the IDIs during the survey fieldwork. The interviews and discussions sought to further interrogate specific issues emerging from the household survey. The FGDs and the interviews were conducted by research teams in the same clusters where the household survey was conducted. All interviews and discussions were audiorecorded with participants' consent. Separate FGDs were conducted for men and women. All interviews were conducted in Arabic.

\section{Data Management and Analysis}

Quantitative data were double entered using the Statistical Package for Social Sciences (SPSS) software (Version 24). Frequency tables were generated for the all variables of the study to check the data entry and to ensure data quality. Univariate and bivariate statistics were computed to summarise the descriptive characteristics of the sample and to assess the factors associated with the final decision to circumcise the youngest daughter in the household or not. The decision around FGM/C was measured using a single item referring to the youngest daughter in the householdwhat was the decision that resulted from the discussion about circumcision? Possible responses were to circumcise the girl, not to circumcise the girl or to postpone the decision. For the bivariate and multivariate analysis, a binary variable (to circumcise/not to circumcise) was created. Variables that were significantly associated with the primary dependent variable at bivariate level were included in a multivariable logistic regression model to identify the predictors of decision-making about FGM/C. A p-value of less than 0.05 was considered statistically significant.

Audio recordings of the IDIs and FGDs were transcribed. Transcripts were then coded manually and categorised into emerging themes and patterns. Findings were generated based on the research questions and the emerging themes and patterns from the initial data analysis. Qualitative methods findings were integrated with the survey findings. Expressive quotes were selected from the transcription, translated into English and presented in the text.

\section{Ethical Considerations and Positionality}

Ethical approval for the study was granted by the Population Council's Institutional Review Board (IRB) and the Research Review Board of Ahfad University for Women (AUW). Potential study participants were briefed about the aim of the study and methods to be used, institutional affiliations of the researchers, anticipated benefits and potential risks and follow-up of the study, discomfort that participation may entail, right to abstain from participating in the study, or to withdraw from it at any time without reprisal and measures to ensure confidentiality of information provided. All participants provided signed informed consent prior to participation.

Although the four main researchers involved in this study are middle class, university staff, based in Khartoum and known to oppose all forms of FGM/C, we were mindful of the importance of remaining professional, independent and impartial in the way we conducted our study and interpreted and presented our results and conclusions. To build trust and improve our understanding of the community, the study team recruited community facilitators from each of the localities and most data collectors were well-trained men and women from the local community. 


\section{Results}

\section{Sociodemographic Characteristics of Surveyed Households}

The socio-demographic characteristics of the surveyed households are summarised in Table 3. The calculated average household size ranged between six and seven persons. Most households (61.2 percent) were living in an urban area. Khartoum had a higher proportion of urban residents than Gedaref (68.2 percent compared to 50.2 percent). Most households ( 86 percent) were maleheaded, reflecting the predominantly patriarchal system across communities. Overall, 11 percent of household heads had never been to school, 12 percent had informal education (Khalwa Quranic school) and the rest (77 percent) had formal education. Most respondents (81 percent) classified their households as middle-income, while 15 percent classified their households as lowincome.

Table 3. Socio-demographic characteristics of surveyed households.

\begin{tabular}{|c|c|c|c|c|c|c|}
\hline & \multicolumn{2}{|c|}{$\begin{array}{l}\text { Gedaref } \\
(n=201)\end{array}$} & \multicolumn{2}{|c|}{$\begin{array}{l}\text { Khartoum } \\
(n=314)\end{array}$} & \multicolumn{2}{|c|}{$\begin{array}{c}\text { Total } \\
(\mathrm{N}=515)\end{array}$} \\
\hline & $\mathbf{N}$ & $\%$ & $\mathbf{N}$ & $\%$ & $\mathbf{n}$ & $\%$ \\
\hline \multicolumn{7}{|l|}{ Areas of residence } \\
\hline Urban & 101 & 50.2 & 214 & 68.2 & 315 & 61.2 \\
\hline Rural & 100 & 49.8 & 100 & 31.8 & 200 & 38.8 \\
\hline \multicolumn{7}{|l|}{ Gender of household head } \\
\hline Male & 190 & 94.5 & 255 & 81.2 & 445 & 86.4 \\
\hline Female & 8 & 4.0 & 27 & 8.6 & 35 & 6.8 \\
\hline Missing & 3 & 1.5 & 32 & 10.2 & 35 & 6.8 \\
\hline \multicolumn{7}{|l|}{ Education level of household head } \\
\hline Illiterate & 24 & 11.9 & 30 & 9.6 & 54 & 10.5 \\
\hline Khalwa (Quranic school) - informal & 19 & 9.5 & 38 & 12.1 & 57 & 11.1 \\
\hline Primary & 51 & 25.4 & 83 & 26.4 & 134 & 26.0 \\
\hline Secondary & 67 & 33.3 & 76 & 24.2 & 143 & 27.8 \\
\hline University/post-graduate & 37 & 18.4 & 54 & 17.2 & 91 & 17.7 \\
\hline Missing & 3 & 1.5 & 32 & 10.2 & 36 & 7.0 \\
\hline \multicolumn{7}{|l|}{ Age of wife (years) } \\
\hline$<30$ & 50 & 24.9 & 43 & 13.7 & 93 & 18.1 \\
\hline 30- 39 & 58 & 28.9 & 94 & 29.9 & 152 & 29.5 \\
\hline $40-49$ & 57 & 28.4 & 91 & 29.0 & 148 & 28.7 \\
\hline$\geq 50$ & 32 & 15.9 & 64 & 20.4 & 96 & 18.6 \\
\hline Missing & 4 & 2.0 & 22 & 7.0 & 26 & 5.0 \\
\hline
\end{tabular}




\begin{tabular}{|c|c|c|c|c|c|c|}
\hline & \multicolumn{2}{|c|}{$\begin{array}{l}\text { Gedaref } \\
(n=201)\end{array}$} & \multicolumn{2}{|c|}{$\begin{array}{l}\text { Khartoum } \\
(n=314)\end{array}$} & \multicolumn{2}{|c|}{$\begin{array}{c}\text { Total } \\
(\mathrm{N}=515)\end{array}$} \\
\hline & $\mathbf{N}$ & $\%$ & $\mathbf{N}$ & $\%$ & $\mathbf{n}$ & $\%$ \\
\hline \multicolumn{7}{|l|}{ Education level of wife } \\
\hline Illiterate & 30 & 14.9 & 47 & 15.0 & 77 & 15.0 \\
\hline Khalwa (Quranic school) - informal & 13 & 6.5 & 23 & 7.3 & 36 & 7.0 \\
\hline Primary & 70 & 34.8 & 123 & 39.2 & 193 & 37.5 \\
\hline Secondary & 51 & 25.4 & 65 & 20.7 & 116 & 22.5 \\
\hline University/post-graduate & 33 & 16.4 & 32 & 10.2 & 65 & 12.6 \\
\hline Missing & 4 & 2.0 & 24 & 7.6 & 28 & 5.4 \\
\hline \multicolumn{7}{|l|}{ Number of household members } \\
\hline $2-5$ & 86 & 42.8 & 76 & 24.2 & 162 & 31.4 \\
\hline $6-10$ & 105 & 52.2 & 213 & 67.8 & 318 & 61.6 \\
\hline $11-15$ & 10 & 5.0 & 23 & 7.3 & 33 & 6.4 \\
\hline $16+$ & 0 & 0.0 & 2 & 0.6 & 2 & 0.4 \\
\hline \multicolumn{7}{|l|}{ Perceived wealth status } \\
\hline High income & 14 & 7.0 & 7 & 2.2 & 21 & 4.1 \\
\hline Middle income & 160 & 79.6 & 255 & 81.2 & 415 & 80.6 \\
\hline Low income & 26 & 12.9 & 50 & 15.9 & 76 & 14.8 \\
\hline Missing & 1 & 0.5 & 2 & 0.6 & 3 & 0.6 \\
\hline
\end{tabular}

In terms of the personal experiences that influenced female respondents' views on FGM/C, Table 4 below shows that nearly half were influenced by being cut themselves (49 percent) or experiences of being uncut (three percent). Others were influenced by either witnessing the suffering of a circumcised girl (11 percent), attending an FGM/C operation (four percent) or attending a pro- or anti-FGM/C religious lecture or meeting (11 percent). 
Table 4. Experiences that affected female respondents' views about FGM/C ( $N=354)$.

\begin{tabular}{lcc} 
Experience $^{\dagger}$ & n & Percent \\
\hline Personal experience as circumcised woman & 173 & 48.9 \\
Personal experience as uncircumcised woman & 10 & 2.8 \\
Attended an FGM operation & 13 & 3.7 \\
Witnessed suffering circumcised girl & 37 & 10.5 \\
Attended pro-FGM religious lecture & 19 & 5.4 \\
Attended anti-FGM religious lecture & 15 & 4.2 \\
Attended pro-FGM religious meeting & 39 & 11.0 \\
Attended anti-FGM religious meeting & 25 & 7.1 \\
Others & 71 & 20.1 \\
\hline †Multiple responses allowed & &
\end{tabular}

\section{Socio-demographic Characteristics of Qualitative Interview Participants}

The number of participants in each FGD varied but mostly ranged from five to nine persons. Two of the male FGDs, both held inside a mosque at the request of local leaders, had 14 and 19 participants each. Most FGD participants were aged between 40 and 59 years. The youngest participant was 18 years and the oldest were aged between 70 and 79 years.

The women who participated in the FGDs were mostly housewives but included some local teachers and young educated married and unmarried girls. The men were mostly self-employed (e.g., farmers) or wage labourers. Some men were employed in the private sector, while others were senior government officials, medical doctors, teachers and university students and graduates.

The women and men who participated in the IDIs were all local leaders and activists, such as women unionist leaders, heads of local associations, religious teachers, ethnic group leaders, members of popular committees, staff from community-based organisations, school teachers, and local activists. Their ages ranged between 21 and 60 years.

\section{FGM/C Practice in Surveyed Households}

Descriptive statistics concerning the practise of FGM/C in surveyed households are summarised in Table 5. This table shows two different but potentially related and relevant issues. Firstly, it summarises the FGM/C status of the wife / female head of household (either reported by her or the primary respondent in each household) and the girls who are younger than 20 years in the household. It also summarises the type of $\mathrm{FGM} / \mathrm{C}$ that was performed. It also presents information on certain aspects of the cutting of the youngest circumcised daughter in the household.

FGM/C was widely practised in participating households with 47 percent of young women and girls younger than 20 years reported to be cut. Seventy-four percent of the youngest cut women and girls aged 19 years or younger in the households were reported to have had the "sunna" cut, while about 13 percent were reported to have had the pharaonic cut (Figure 3). There was a high degree of medicalisation of FGM/C with about 67 percent of the youngest women and girls having been cut by trained midwives, one percent by a nurse, and 2 percent by a physician. Despite the high number of young women and girls who were cut by a health professional, 55 percent of girls had 
been cut in the family home while 18 percent were cut in the house of an extended family member. Only one percent of girls had reportedly been cut in a health facility (Table 5).

Table 5. FGM/C practice in surveyed households.

\begin{tabular}{|c|c|c|c|c|c|c|}
\hline & \multicolumn{2}{|c|}{$\begin{array}{l}\text { Gedaref } \\
(n=201)\end{array}$} & \multicolumn{2}{|c|}{$\begin{array}{l}\text { Khartoum } \\
(n=314)\end{array}$} & \multicolumn{2}{|c|}{$\begin{array}{c}\text { Total } \\
(\mathrm{N}=515)\end{array}$} \\
\hline & $\mathbf{n}$ & $\%$ & $\mathbf{n}$ & $\%$ & $\mathbf{N}$ & $\%$ \\
\hline $\begin{array}{l}\text { Prevalence of FGM/C among the } \\
\text { respondents or their wives }\end{array}$ & 167 & 83.1 & 261 & 83.1 & 428 & 83.1 \\
\hline \multicolumn{7}{|l|}{$\begin{array}{l}\text { FGM/C status of the youngest } \\
\text { woman/girl under } 20 \text {-years }\end{array}$} \\
\hline Circumcised & 68 & 33.8 & 174 & 55.4 & 242 & 47.0 \\
\hline \multirow[t]{3}{*}{ Uncircumcised } & 133 & 66.2 & 140 & 44.6 & 273 & 52.6 \\
\hline & \multicolumn{2}{|c|}{$(n=68)$} & \multicolumn{2}{|c|}{$(n=174)$} & \multicolumn{2}{|c|}{$(\mathrm{N}=242)$} \\
\hline & $\mathrm{n}$ & $\%$ & $\mathbf{n}$ & $\%$ & $\mathbf{N}$ & $\%$ \\
\hline
\end{tabular}

Type of FGM/C performed on youngest woman/girl under 20-years

$\begin{array}{lcccccc}\text { Pharaonic } & 13 & 19.1 & 18 & 10.3 & 31 & 12.8 \\ \text { Advanced "sunna" (Sandwich) } & 3 & 4.4 & 10 & 5.7 & 13 & 5.4 \\ \text { Sunna } & 50 & 73.5 & 129 & 74.1 & 179 & 74.0 \\ \text { Other } & 0 & 0 & 4 & 2.3 & 4 & 1.7 \\ \text { Don't know } & 2 & 2.9 & 11 & 6.3 & 13 & 5.4 \\ \text { Missing } & 0 & 0 & 2 & 1.1 & 2 & 0.8 \\ \text { rcumciser who performed the } & & & & & & \\ \text { M } / \text { procedure on youngest } & & & & & & \\ \text { Physician } & & & & & & \\ \text { Trained midwife } & 1 & 1.5 & 4 & 2.3 & 5 & 2.1 \\ \text { Untrained midwife } & 48 & 70.6 & 115 & 66.1 & 163 & 67.4 \\ \text { Nurse } & 3 & 4.4 & 15 & 8.6 & 18 & 7.4 \\ \text { Grandmothers } & 0 & 0.0 & 2 & 1.1 & 2 & 0.8 \\ \text { Other } & 0 & 0.0 & 6 & 3.4 & 6 & 2.5 \\ \text { Missing } & 2 & 2.9 & 6 & 3.4 & 8 & 3.3 \\ \end{array}$

Location where circumcision took place for the youngest daughter

$\begin{array}{lcrrrrr}\text { Current place of residence } & 46 & 67.6 & 115 & 66.1 & 161 & 66.5 \\ \text { Family's home-village/town } & 7 & 10.3 & 28 & 16.1 & 35 & 14.5 \\ \text { Other } & 0 & 0.0 & 6 & 3.4 & 6 & 2.5 \\ \text { Missing } & 15 & 22.1 & 25 & 14.4 & 40 & 16.5\end{array}$




\begin{tabular}{|c|c|c|c|c|c|c|}
\hline $\begin{array}{l}\text { Premises where circumcision } \\
\text { procedure was performed for the } \\
\text { youngest daughter }\end{array}$ & & & & & & \\
\hline House of the nuclear family & 34 & 50.0 & 99 & 56.9 & 133 & 55.0 \\
\hline House of the extended family & 18 & 26.5 & 26 & 14.9 & 44 & 18.2 \\
\hline Health facility & 0 & 0.0 & 3 & 1.7 & 3 & 1.2 \\
\hline House of the midwife & 1 & 1.5 & 16 & 9.2 & 17 & 7.0 \\
\hline House of neighbours/ friends & 0 & 0.0 & 1 & 0.6 & 1 & 0.4 \\
\hline Other & 1 & 1.5 & 4 & 2.3 & 5 & 2.1 \\
\hline Missing & 14 & 20.6 & 25 & 14.4 & 39 & 16.1 \\
\hline
\end{tabular}

Figure 3. Type of cut among young women and girls aged 0-19 years in surveyed households $(\mathrm{N}=\mathbf{2 4 2})$.

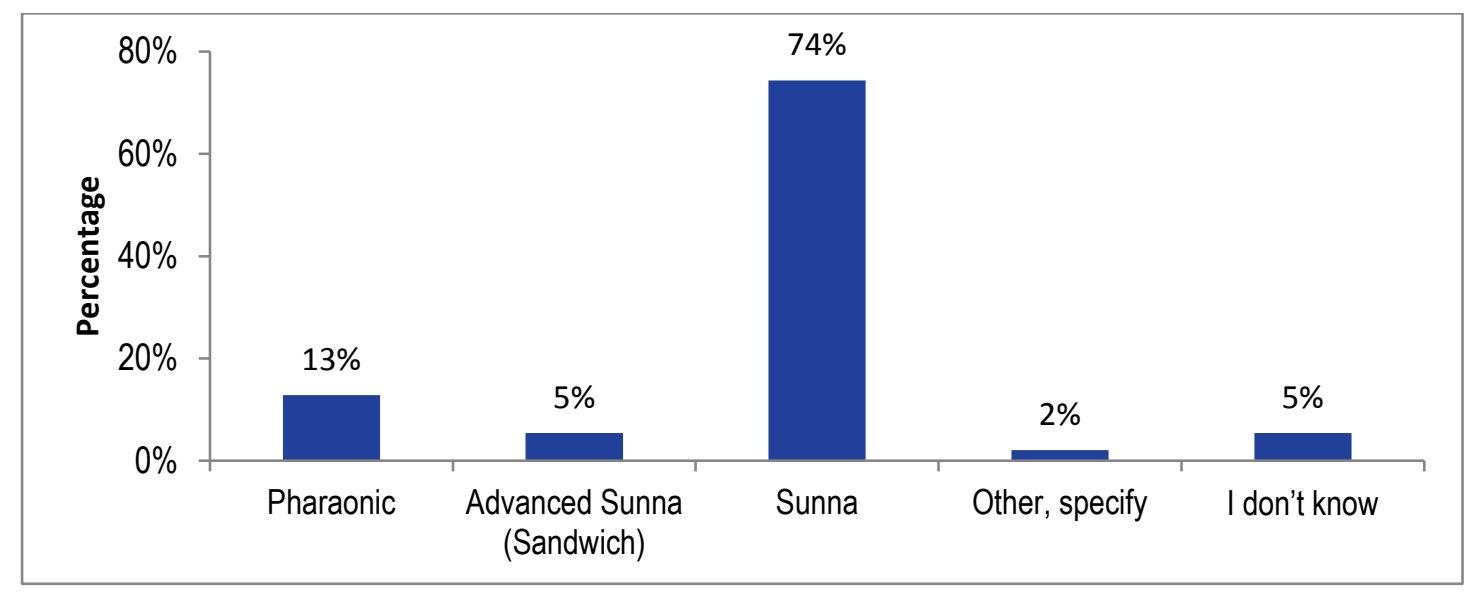

\section{Preparing for and performing FGM/C}

The practise of $\mathrm{FGM} / \mathrm{C}$ is usually a process beginning with initial preparations for the event. Table 6. summarises survey responses about the people involved in different FGM/C-related activities. Results indicate that most activities primarily involved women (mostly mothers, grandmothers and aunts). Although a mix of female and male family members, friends and neighbours were reported to have attended the actual event, either the mothers (71 percent) or maternal grandmothers (14 percent) was involved in making the deal with the circumciser. Payment of fees for the circumcision was primarily done by the girl's mother (57 percent) or father (38 percent). 
Table 6. People involved in FGM/C-related activities for the youngest circumcised girl in participating households $(\mathrm{N}=242)$.

\begin{tabular}{lcccccccc}
\hline Persons involved & $\begin{array}{l}\text { Persons who } \\
\text { prepared for } \\
\text { the event }\end{array}$ & $\begin{array}{l}\text { Persons who } \\
\text { attended the } \\
\text { event* }\end{array}$ & $\begin{array}{l}\text { Person who } \\
\text { made the } \\
\text { deal with the } \\
\text { circumciser* }\end{array}$ & $\begin{array}{l}\text { Person who } \\
\text { paid the fees }\end{array}$ \\
\cline { 2 - 9 } & $\mathbf{n}$ & $\%$ & $\mathbf{n}$ & $\%$ & $\mathbf{n}$ & $\%$ & $\mathbf{n}$ & $\%$ \\
\hline Mother & 198 & 81.8 & 142 & 58.7 & 172 & 71.1 & 137 & 56.6 \\
Father & 52 & 21.5 & 51 & 21.1 & 15 & 6.2 & 92 & 38.0 \\
Sister & 13 & 5.4 & 47 & 19.4 & - & - & - & - \\
Brother & 8 & 3.3 & 32 & 13.2 & 3 & 1.2 & 1 & 0.4 \\
Maternal grandmother & 125 & 51.7 & 110 & 45.5 & 34 & 14.0 & 10 & 4.1 \\
Paternal grandmother & 72 & 29.8 & 83 & 34.3 & 11 & 4.5 & 4 & 1.7 \\
Uncle & 11 & 4.5 & 45 & 18.6 & 0 & 0.0 & 1 & 0.4 \\
Aunt & 67 & 27.7 & 116 & 47.9 & 11 & 4.5 & 6 & 2.5 \\
Friends or neighbours & 27 & 11.2 & 103 & 42.6 & 0 & 0.0 & 17 & 7.0 \\
\hline Daughter & - & - & - & - & 2 & 0.8 & - & - \\
\hline No one & 16 & 6.6 & 14 & 5.8 & - & - & - & - \\
\hline Others & 7 & 2.9 & 12 & 5.0 & - & - & - & - \\
\hline *:Multiple responses allowed & & & & & & & & \\
\hline
\end{tabular}

\section{Exposure to FGM/C-related Information}

The practice of FGM/C in Sudan is still controversial despite the long-history of efforts to end it that date back to the early 1940s. As such, most individuals and communities are exposed to both proand anti-FGM/C information. Table 7 summarises the survey findings on the sources from which households received FGM/C-related information and the survey respondents' perceptions around the most influential sources. Results show that the same channels of information are often used to advocate for or oppose FGM/C. The most frequently reported source of pro-FGM/C information was home visits by a health promoter-volunteer who works in a community to facilitate health service provision and conducts health awareness-raising activities ( 55 percent), followed by the public discussions about FGM/C and women's issues (38 percent) and television (36 percent). The most frequently reported source of anti-FGM/C information was the radio (38 percent), followed by role-plays/lectures (24 percent) community dialogues (19 percent), public discussions on FGM/C or women's issues (19 percent), the television (19 percent), and community public declarations (18 percent). As shown in Table 8, the most influential source/channel of information was the television (60 percent), followed by health awareness talks ( 22 percent) and family members (19 percent). 
Table 8. Households' sources of FGM/C information.

\begin{tabular}{|c|c|c|c|c|c|c|}
\hline \multirow[t]{2}{*}{ Information source } & \multicolumn{2}{|c|}{$\begin{array}{l}\text { Pro-FGM/C } \\
\text { information }{ }^{\dagger}\end{array}$} & \multicolumn{2}{|c|}{$\begin{array}{l}\text { Anti-FGM/C } \\
\text { information }^{\dagger}\end{array}$} & \multicolumn{2}{|c|}{$\begin{array}{c}\text { Most influential } \\
\text { FGM/C } \\
\text { information } \\
\text { source }^{\dagger}\end{array}$} \\
\hline & $\begin{array}{c}n^{*} \\
(205)\end{array}$ & $\%$ & $\begin{array}{c}n^{* *} \\
(392)\end{array}$ & $\%$ & $\begin{array}{c}N \\
(515)\end{array}$ & $\%$ \\
\hline TV & 73 & 36 & 74 & 19 & 311 & 60.4 \\
\hline Radio & 31 & 15 & 150 & 38 & 85 & 16.5 \\
\hline Role-playllecture & 27 & 13 & 95 & 24 & 80 & 15.5 \\
\hline Religious lecture & 10 & 5 & 36 & 9 & 59 & 11.5 \\
\hline Education program & 18 & 9 & 29 & 7 & 66 & 12.8 \\
\hline Health awareness campaigns & 26 & 13 & 38 & 10 & 111 & 21.6 \\
\hline Family members & 19 & 9 & 49 & 13 & 99 & 19.2 \\
\hline $\begin{array}{l}\text { Community dialogue /group } \\
\text { discussion }\end{array}$ & 59 & 29 & 74 & 19 & 61 & 11.8 \\
\hline Home visit by health promoter & 112 & 55 & 60 & 15 & 24 & 4.7 \\
\hline $\begin{array}{l}\text { Public discussion about FGM } \\
\text { or women issues }\end{array}$ & 78 & 38 & 76 & 19 & 35 & 6.8 \\
\hline Brochure/posters & 5 & 2 & 41 & 10 & 41 & 8.0 \\
\hline $\begin{array}{l}\text { Lecture on harmful traditional } \\
\text { practices }\end{array}$ & 7 & 3 & 61 & 16 & 38 & 7.4 \\
\hline Saleema Campaign & 5 & 2 & 54 & 14 & 47 & 9.1 \\
\hline Community public declaration & 5 & 2 & 72 & 18 & 19 & 3.7 \\
\hline Not applicable & 13 & 6 & 5 & 1 & & \\
\hline Others & 17 & 8 & 10 & 3 & & \\
\hline
\end{tabular}

${ }^{\dagger}$ Multiple responses allowed

* Total number of respondents exposed to pro-FGM/C information

** Total number of respondents exposed to anti-FGM/C information

\section{Reasons for Performing FGM/C}

The qualitative interviews provided deeper insights into the reasons for and against female circumcision. According to one female community leader in Khartoum, who called for the abandonment of the practice, circumcision "has no advantages at all, it will be better if people abandon it." Similarly, another FGD female participant in Khartoum noted "it has no advantages, but they say it increases sexual enjoyment for men. The uncircumcised [woman] gives birth fast and easy, but they say the uncircumcised will be exposed to many problems."

The next section summarises the key reasons for the practice of FGM/C as identified from a thematic analysis of the qualitative interviews. The reasons can be broadly assembled into five themes: regulating women sexual behaviour by reducing their sexual desire and ensuring their 
chastity and fidelity, conforming to culture and traditions, obeying religious traditions, enhancing hygiene and health and avoiding stigma and enhancing marriageability.

\section{Regulating women's sexuality and sexual behaviour}

Many qualitative interview respondents noted the importance of removing the clitoris and in some cases also the labia minor because removal reduces a girl's sexual desire and, thus, 'protects her' by enhancing her chastity. FGM/C was perceived to be particularly important for the 'protection' of girls before marriage and to protect the family's honour. These views are highlighted in the following quotes:

"Some people practise it because they believe that it reduces the sexual desire for girls, if this desire is high, it must be performed, because such desire could spoil the girl."

Female community leader, Khartoum

"I honestly believe that if the sexual desire of a girl is high, this can be a problem because this can subvert the girl."

Female community leader, Khartoum

"People in this area fear the disgrace that may come if they leave their daughters without circumcision, as this will leave her with high sexual desire and this may lead her to commit a sin (meaning pre-marital sex) and cause her family problems. Also, they think that circumcision can protect the girl from rape, as it makes it difficult for him to do it. Even if she was raped, it will be possible to re-circumcise her and cover the effects of rape."

School teacher, Gedaref

"We do female circumcision because it is important for preserving the honour of the girl (meaning her virginity until she gets married) and so that she can get married; they say if you do not circumcise her, you have not protected her."

Woman, FGD, Khartoum

"A girl's sexual desires and arousal will increase if she was left with nothing cut, she may commit a mistake...women will also ask you, 'why are you leaving your daughter just like this (uncut)?' They can really cause you paranoia ... they might also not marry your daughters."

Female community leader, Khartoum

'The uncircumcised girl is exposed to deviation because of the excessive sexual desire.'

$$
\text { Man, FGD, Khartoum }
$$

Some respondents noted that while limiting girls' sexual desires was good before marriage, FGM/C was also noted to limit sexual enjoyment in marriage. This view is highlighted in the following quotes:

"The circumcised girl has a limited sexual desire, this can be good before she gets married because she can control her sexual desire. When she gets married this can be a problem because she will not enjoy sex with her husband and he will find her cold and not responsive... the husband may also not satisfy her sexually."

Man, FGD, Khartoum

"Yes, circumcision has many advantages for the girl; it saves her by reducing her sexual desire and her desire for love and circumcised girls are preferred by men. As for its 
disadvantage, it reduces sexual desire (after marriage) and incomplete response with their husbands, exposure to infections, pain during menstruation and at giving birth."

\section{School teacher, Gedaref}

However, some respondents noted that FGM/C enhanced men's sexual enjoyment. For example, a woman who participated in an FGD in Gedaref stated: "it gives pleasure to the husband."

\section{Conformity with culture and tradition}

Some respondents noted that FGM/C was important because it was part of their tradition or culture. Performing FGM/C was therefore reportedly done out of respect for culture and traditions. These views are illustrated in the following quotes:

"For many families, the best option is to practise it, at least out of respect for customs and traditions. I know that it causes infections and bleeding for girls; it also causes period cramps."

Female community leader, Khartoum

"Since we've grown up, we found that our grandmothers practise it, we cannot abandon it and get the community to disown us and call us names."

Female community leader, Khartoum

Women are reportedly viewed as the symbols and the guardians of morality and social values and are expected to conform to traditions and social norms. As such, being a 'true' and 'decent' woman seemed to be equated with being a conforming woman. As one woman in an FGD in Gedaref put in, "If you oppose (FGM/C), then you are not considered a decent woman, you are not even a woman." Another woman in an FGD in Gedaref similarly noted, "The decision is largely in the hands of the mother and all mothers would conform to traditions regardless of their education or status."

In trying to balance societal expectations and what they personally believe, some families were noted to deceive girls into believing that they had been cut when they had not. As illustrated in the following quotation from a young woman in Khartoum, deception protected the girls from stigma:

"In my own family, we have abandoned all forms of female circumcision, due to education awareness and the support of our great-grandfather. But it was still important for us to pretend that we have circumcised our daughters to prevent them from feeling ashamed or from having people call them names. So, I did henna (temporary decorative tattoos) for them and bought them new clothes and called the midwife. I agreed with the midwife to deceive them with a simple injection and then tie up their legs together and let them lie down and sleep."

\section{$\mathrm{FGM} / \mathrm{C}$ as a religious duty}

Some respondents reported that FGM/C is a religious duty and an integral part of Islamic teaching. The religious discourse around FMG/C seems to play an important role in driving the association between FGM/C and Islam. For example, the word "sunna"-Islamic customs and practices based on Prophet Muhammad's words and deeds-was used to refer to the most widely practised type of FGM/C. Further, according to a group of women in Gedaref, female circumcision was described as a "religious tradition of our Prophet".

\section{Enhancing hygiene and ensuring cleanliness}

Some respondents noted that FGM/C enhances feminine hygiene and cleanliness, as well as prevents disease. These views are illustrated in the following quotations: 
"Women in this area talk about "how come a girl can be left "ghalfa" (a derogatory word for uncut girls)'. They talk about removing the clitoris because it causes a very nasty smell.... they tell the midwife to remove it."

Woman, FGD, Khartoum

"Its advantage is that it's a kind of cleanness for the girl, it makes no chance for dirt."

Woman, FGD, Khartoum

"Of course, female circumcision has many advantages; it maintains customs and traditions of the family and it curbs the excessive sexual desire of the girl. It also prevents diseases."

Woman, FGD, Gedaref

\section{Avoiding social stigma and enhancing marriageability}

Within a context where FGM/C is widely practised, deviation from such practice is risky, as the community may shun and ostracise 'deviants' and stigmatise their non-compliance. According to some respondents, the fear of stigma made it difficult for community members to abandon FGM/C. These views are illustrated in the following quotes:

"When people discuss female circumcision in this area, they say they do not like it, but are compelled to do it, because the community is in favour of its continuation... we have cases where the girl herself asks to be circumcised because her colleagues at school call her names."

Woman, FGD, Gedaref

"Some women in our area call the uncircumcised girl 'Khor Abu Fargha' (a seasonal water stream in the area; making reference to being morally loose and ugly looking)."

Woman, FGD, Gedaref

The stigma of being uncut was not limited to uncircumcised daughters but was reported to extend to the entire family. For example, a woman who participated in an FGD in Gedaref noted, "If you do not do it, your in-laws may call you names".

Relatedly, FGM/C was also considered essential for marriage. As illustrated in the following quotations, respondents noted that girls who were not circumcised would not get married. As a result, even those who were against the practice, felt pressurised to perform FGM/C so that their daughters could get married.

"Women will tell you that if you do not circumcise your daughter, she will never get married."

Female community leader, Khartoum

"We practise it because men will not marry an uncircumcised girl."

Woman, FGD, Gedaref

"We know that it is not good, but if we do not cut them, no one will take (marry) them."

Woman, FGD, Gedaref

\section{FGM/C-related Decision-Making Process}

\section{Timing of FGM/C decisions}

Results from the household survey suggest that decisions on FGM/C begin when girls are aged between three years and nine years (Figure 4). However, according to participants in the FGDs and IDIs, while deliberation can start when the girl is as young as three years old, girls are usually 
cut just before or after they start attending school (five-nine years). Most (90\%) of girls were reportedly cut when they were younger than ten years.

Figure 4. Age at which discussions on FGM/C were initiated ( $N=397)$.

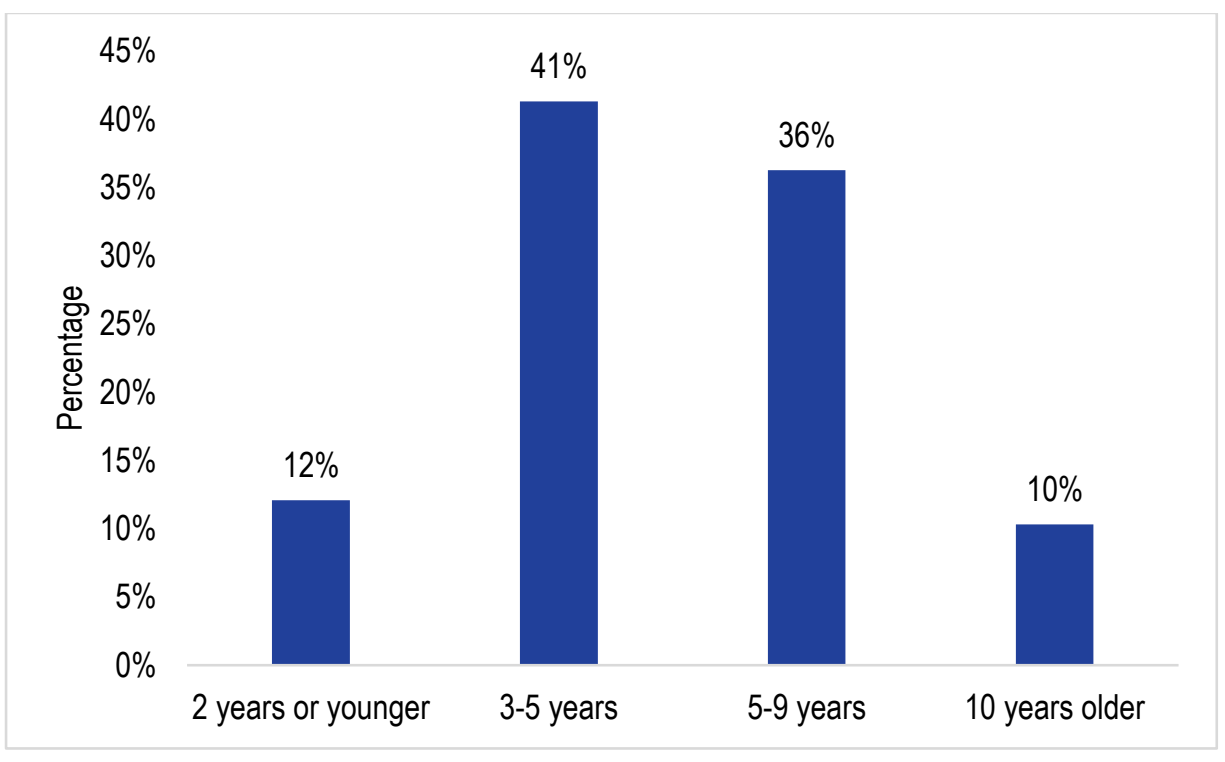

Qualitative interview respondents noted that cutting girls at an early age was necessary so that when they start school and interact with others outside their home, girls are 'protected'. They also noted that young girls were less likely to resist or refuse the cut, and that the procedure was best done at this age because the genitalia were fully formed. Some IDIs and FGD participants noted that girls were most likely to be cut during school holidays and religious festivals because these are occasions when there are extended family gatherings and annual visits to the grandparents and other relatives. These views are illustrated in the following quotations from IDI and FGD participants:

"People in this area are performing female circumcisions when the girls are about, four, five or six - that is before she starts schooling, because at this age the girls are too young, they have no opinion and they cannot reject it."

Female community leader, Khartoum

"In our area, circumcisions are often performed during school holidays and a'ayad (religious festivals). They are often done for girls before they are four, five or six years old. Before they start school, but in all cases before they reach nine years. This age is important because at this age the genitalia is fully grown and the procedure works."

Woman, FGD, Gedaref

"We circumcised our girls at an early age because if they grow up they might refuse, and it will be difficult to force them."

Religious teacher, Khartoum

"The main school break is often the time when most people perform the procedure. In most cases, the mother will raise the issue just before the girl is due to start schooling. The age of five or six years is the main time as the family will be keen to circumcise their daughter before starting going out to school... because girls stay long hours in school from the morning to afternoon, and the circumcision is a guarantee and a protection for them."

Female community leader, Khartoum 


\section{Key people involved in FGM/C decisions}

Table 8 summarises survey findings on FGM/C decision-making. About 39 percent of the respondents mentioned that the girl's mother initiated the discussion on the need to circumcise her daughter, while 16 percent stated that maternal grandmothers initiated the discussion. Discussions on the type of cut extended beyond the nuclear family and about 23 percent and 31 percent of respondents noted that the maternal and paternal grandmothers, respectively, were involved in these discussions. Men were also involved in these discussions with 21 percent of respondents noting that the girl's father was involved in discussions on the type of cut while about two percent stated that uncles were involved. Eleven percent of the respondents reported that the midwife who performed the procedure was involved in the discussions on the type of cut.

Table 8. FGM/C decision-making in surveyed households.

\begin{tabular}{|c|c|c|c|c|c|c|}
\hline & \multicolumn{2}{|c|}{$\begin{array}{l}\text { Gedaref } \\
(n=165)\end{array}$} & \multicolumn{2}{|c|}{$\begin{array}{l}\text { Khartoum } \\
(n=263)\end{array}$} & \multicolumn{2}{|c|}{$\begin{array}{c}\text { Total } \\
(\mathrm{N}=428)^{*}\end{array}$} \\
\hline & $\mathbf{n}$ & $\%$ & $\mathbf{n}$ & $\%$ & $\mathbf{n}$ & $\%$ \\
\hline \multicolumn{7}{|l|}{$\begin{array}{l}\text { Who initiates discussions on the } \\
\text { need to circumcise girls? }\end{array}$} \\
\hline Mother & 113 & 68.5 & 53 & 20.2 & 166 & 38.8 \\
\hline Father & 32 & 19.4 & 6 & 2.3 & 38 & 8.9 \\
\hline Sister & 0 & 0 & 2 & 0.8 & 2 & 0.5 \\
\hline Brother & 1 & 0.6 & 61 & 23.2 & 62 & 14.5 \\
\hline Maternal grandmother & 27 & 16.4 & 42 & 16 & 69 & 16.1 \\
\hline Paternal grandmother & 12 & 7.3 & 5 & 1.9 & 17 & 4.0 \\
\hline Uncle & 0 & 0.0 & 22 & 8.4 & 22 & 5.1 \\
\hline Aunt & 0 & 0.0 & 2 & 0.8 & 2 & 0.5 \\
\hline Friends or neighbours & 3 & 1.8 & 22 & 8.4 & 25 & 5.8 \\
\hline Cannot remember/ don't know & 13 & 7.9 & 23 & 8.7 & 36 & 8.4 \\
\hline Nobody & 25 & 15.2 & 8 & 3 & 33 & 7.7 \\
\hline Others & 4 & 2.4 & 8 & 3 & 12 & 2.8 \\
\hline \multicolumn{7}{|l|}{$\begin{array}{l}\text { Persons involved in deciding the } \\
\text { type of circumcision }\end{array}$} \\
\hline Mother & 52 & 31.5 & 109 & 41.4 & 161 & 37.6 \\
\hline Father & 21 & 12.7 & 27 & 10.3 & 48 & 11.2 \\
\hline Sister & 1 & 0.6 & 2 & 0.8 & 3 & 0.7 \\
\hline Maternal grandmother & 21 & 12.7 & 32 & 12.2 & 53 & 12.4 \\
\hline Paternal grandmother & 22 & 13.3 & 49 & 18.6 & 71 & 16.6 \\
\hline Uncle & 1 & 0.6 & 4 & 1.5 & 5 & 1.2 \\
\hline Aunt & 1 & 0.6 & 19 & 7.2 & 20 & 4.7 \\
\hline
\end{tabular}




\begin{tabular}{|c|c|c|c|c|c|c|}
\hline & \multicolumn{2}{|c|}{$\begin{array}{l}\text { Gedaref } \\
(n=165)\end{array}$} & \multicolumn{2}{|c|}{$\begin{array}{c}\text { Khartoum } \\
(n=263)\end{array}$} & \multicolumn{2}{|c|}{$\begin{array}{c}\text { Total } \\
(\mathrm{N}=428)^{*}\end{array}$} \\
\hline & $\mathbf{n}$ & $\%$ & $\mathbf{n}$ & $\%$ & $\mathbf{n}$ & $\%$ \\
\hline Friends or neighbours & 0 & 0.0 & 3 & 1.1 & 3 & 0.7 \\
\hline $\begin{array}{l}\text { Midwife/person performing the } \\
\text { procedure }\end{array}$ & 1 & 0.6 & 23 & 8.7 & 24 & 5.6 \\
\hline Don't know & 3 & 1.8 & 4 & 1.5 & 7 & 1.6 \\
\hline \multicolumn{7}{|l|}{$\begin{array}{l}\text { Attitudes of persons involved in } \\
\text { initial discussions on FGM/C }\end{array}$} \\
\hline Supporting circumcision & 91 & 55.2 & 118 & 44.9 & 209 & 48.8 \\
\hline Against circumcision & 55 & 33.3 & 23 & 8.7 & 78 & 18.2 \\
\hline Indifferent & 1 & 0.6 & 7 & 2.7 & 8 & 1.9 \\
\hline No clear response & 0 & 0 & 8 & 3.0 & 8 & 1.9 \\
\hline Have different opinions & 5 & 3 & 21 & 8.0 & 26 & 6.1 \\
\hline Others & 26 & 15.8 & 29 & 11.0 & 55 & 12.9 \\
\hline \multicolumn{7}{|l|}{ Final FGM C decision } \\
\hline Circumcise the girl & 83 & 50.3 & 173 & 65.8 & 256 & 59.8 \\
\hline Not to circumcise the girl & 69 & 41.8 & 78 & 29.7 & 147 & 34.3 \\
\hline Postpone decision & 13 & 7.9 & 12 & 4.6 & 25 & 5.8 \\
\hline
\end{tabular}

Note: Multiple responses allowed

*Includes only those households that reported discussions on FGM/C

The attitudes of those who were involved in initial discussions on FGM/C and the final decision reached by the household differed, indicating both the significance of the household deliberations and the relative power and influence of those involved in the decision-making process (Table 8). Nearly half of those involved in the discussions (49 percent) were in favour of circumcision, while 18 percent were against performing the circumcision. The final decision, however, in the majority of the cases ( 60 percent) was to cut the girl. Findings also indicate that some of those involved in initial discussions, primarily health professionals and activities, withdrew from the discussion before the decision was made. The final decision was primarily made by parents (Table 9 ). Thirty percent of respondents noted that the grandmother was involved in making the final decision for instances where the final decision was to cut the girl. Whereas fathers were reported as a final decision maker by 28 percent of respondents when the final decision was to cut, fathers were reported as a final decision maker by 65 percent of respondents when the final decision was not to cut the girl, suggesting that fathers may play a more central role in decision-making when they are not in favour of the girl being cut. 
Table 9. Final decision maker on FGM/C and decision on performing FGM/C *

\begin{tabular}{lcccc}
\hline \multirow{2}{*}{ Decision maker } & \multicolumn{2}{c}{$\begin{array}{c}\text { Not to } \\
\text { circumcise girl }\end{array}$} & \multicolumn{2}{c}{ To circumcise } \\
\cline { 2 - 5 } & $\mathbf{n ( 1 4 7 )}$ & $\%$ & $\mathbf{n ~ ( 2 5 6 )}$ & $\%$ \\
\hline Mother & 112 & 76.2 & 194 & 75.8 \\
Father & 95 & 64.6 & 72 & 28.1 \\
Professional/activist & 31 & 21.1 & 11 & 4.3 \\
Aunt & 11 & 7.5 & 19 & 7.4 \\
Maternal grandmother & 8 & 5.4 & 78 & 30.5 \\
Paternal grandmother & 7 & 4.8 & 43 & 16.8 \\
Sister & 4 & 2.7 & 2 & 0.8 \\
Uncle & 4 & 2.7 & 2 & 0.8 \\
Brother & 3 & 2.0 & 5 & 2.0 \\
Others & 11 & 7.5 & 15 & 5.9 \\
\hline Notes: multiple responses allowed & & & & \\
* Excludes households where the decision was postponed & &
\end{tabular}

When asked who the most influential people in terms of households' decisions on FGM/C were, respondents mentioned a broad network of individuals within and beyond the nuclear and extended family. This suggests that the decision was often a collective rather than an individual decision. Mothers were the most frequently mentioned (43 percent), followed by maternal aunt (18 percent), husbands (16 percent) and maternal grandmother (14 percent) (Table 10). That mothers, aunts and grandmothers were among the most frequently cited influential people suggests that women play a central role in the decision-making process. It is, perhaps, not surprising that brothers also appeared as part of the decision makers, since FGM/C is associated with the desire to regulate women's behaviour, especially their sexual behaviour and brothers often view themselves as protectors of the honour and reputation of the family. Further, the results show that the most influential are people who are most proximate in the social network, namely the nuclear and extended family members and that religious leaders, health professionals and other non-family members are less influential. 
Table 10. Households' perceptions of the most influential persons in relation to FGM/C $(n=515)$.

\begin{tabular}{lcc}
\hline Person & n & Percent \\
\hline Mother & 223 & 43 \\
Maternal aunt & 95 & 18 \\
Father & 81 & 16 \\
Other relatives & 78 & 15 \\
Maternal grandmother & 71 & 14 \\
Religious figures & 61 & 12 \\
Others & 63 & 12 \\
Paternal grandmother & 54 & 10 \\
Friends & 49 & 10 \\
Physician health professionals & 48 & 9 \\
Government official & 37 & 7 \\
\hline NGOs Activists & 15 & 3 \\
\hline Notes: multiple responses allowed & &
\end{tabular}

\section{Reasons for the final FGM/C decision}

Survey respondents were asked to give the reason or justification for the final decision either to cut or not to cut the girl. Fifty-two percent of those in households that decided to cut the girl, reported culture or custom as a reason for the decision, while 33 percent noted that it was a religious duty and 26 percent that it was necessary for chastity (Table 11). On the other hand, the majority of those who decided not to cut justified their decision primarily on grounds of health (57 percent) and marriageability (15 percent). 
Table 11. Reasons and justifications for the FGM/C final decision.

\begin{tabular}{lcccc}
\hline \multirow{2}{*}{ Reason } & \multicolumn{2}{c}{$\begin{array}{c}\text { Not to } \\
\text { circumcise girl }\end{array}$} & $\begin{array}{c}\text { To circumcise } \\
\text { girl }\end{array}$ \\
\cline { 2 - 5 } & $\mathbf{n ~ ( 1 4 7 )}$ & $\%$ & n (256) & $\%$ \\
\hline Health reasons & 84 & 57.1 & 32 & 12.5 \\
Marriageability & 22 & 15.0 & 41 & 16.0 \\
Custom / culture & 12 & 8.2 & 133 & 52.0 \\
A religious duty & 10 & 6.8 & 84 & 32.8 \\
Chastity & 4 & 2.7 & 67 & 26.2 \\
Religiously preferred & 3 & 2.0 & 28 & 10.9 \\
Economic reasons & 3 & 2.0 & 0 & 0.0 \\
Others & 6 & 4.1 & 23 & 9.0 \\
\hline
\end{tabular}

Notes: multiple responses allowed

\section{Predictors of the decision not to cut youngest daughter}

To assess the factors associated with the final decision to cut a girl or not, we ran a multivariable logistic regression model including all variables that were significantly associated with the decision to cut or not cut at bivariate level. The logistic regression analysis results are summarised in Table 12. Compared to households with mothers with university education, those with mothers who had not been to school and mothers with primary education were less likely to decide to leave their daughters uncut (odds ratio $(O R)=0.43, p<.05$ ). Household with mothers who had been circumcised were also less likely to leave their daughters uncut $(O R=0.47, p<.05)$. With regards to the states where the households reside, the households in Gedaref State were approximately twice as likely as those who lived in Khartoum State to leave their daughter uncut (OR $=1.70, p<$ .05). However, rural or urban residence was not a significant predictor of the final decision. Compared to households perceived to be low income households, those perceived to be high or middle-income households were more likely to report a decision to leave their daughter uncut. However, the odds ratio was only statistically significant for the difference between middle-income households and low-income households ( $O R=2.44, p<.05)$. With respect to exposure to FGM/C related information, respondents who reported no exposure to pro-FGM/C information were nearly two times more likely than those who had been exposed to this information to report a decision to leave their daughter uncut $(O R=1.99, p<.05)$. Similarly, those not reporting exposure to antiFGM/C information were less likely to report a decision to leave their daughter uncut $(O R=0.38$, $\mathrm{p}<$.05). However, exposure to any FGM/C-related materials or information was not a predictor for reporting a decision to leave their daughter uncut. 
Table 6. Predictors of the decision not to cut youngest daughter.

\begin{tabular}{|c|c|c|c|c|c|c|}
\hline \multirow{3}{*}{ Predictors } & \multicolumn{2}{|c|}{ Decision } & \multirow{3}{*}{$\begin{array}{c}\text { Row } \\
n\end{array}$} & \multirow{3}{*}{ OR $_{\mathrm{adj}}$} & \multicolumn{2}{|c|}{$95 \%$ C.I of OR } \\
\hline & $\begin{array}{c}\text { Not to } \\
\text { circumcise } \\
(\%)\end{array}$ & $\begin{array}{c}\text { To } \\
\text { circumcise } \\
(\%)\end{array}$ & & & Lower & Upper \\
\hline & $n=147$ & $\mathrm{n}=\mathbf{2 5 6}$ & & & & \\
\hline \multicolumn{7}{|l|}{ Mother's level of education } \\
\hline None & $12(20.3)$ & $47(79.7)$ & 59 & $0.32^{*}$ & 0.128 & 0.788 \\
\hline Khalwa (religious school) & $12(38.7)$ & $19(61.3)$ & 31 & 0.58 & 0.214 & 1.564 \\
\hline Primary/elementary & $45(30.4)$ & $103(69.6)$ & 148 & $0.43^{*}$ & 0.210 & 0.889 \\
\hline Secondary & $45(49.5)$ & $46(50)$ & 91 & 0.97 & 0.454 & 2.059 \\
\hline $\begin{array}{l}\text { University/post graduate } \\
\text { (ref) }\end{array}$ & $27(54)$ & $23(46)$ & 50 & & & \\
\hline \multicolumn{7}{|l|}{ Mother's circumcision status } \\
\hline Circumcised & $119(34.3)$ & $228(65.7)$ & 347 & $0.47^{*}$ & 0.243 & 0.917 \\
\hline Not circumcised (ref) & $28(50)$ & $28(50)$ & 56 & & & \\
\hline \multicolumn{7}{|l|}{ State } \\
\hline Gedaref & $69(45.4)$ & $83(54.6)$ & 152 & $1.70^{*}$ & 1.017 & 2.845 \\
\hline Khartoum (ref) & $78(31.1)$ & $173(68.9)$ & 251 & & & \\
\hline \multicolumn{7}{|l|}{ Area of residence } \\
\hline Urban & $100(41)$ & $144(59)$ & 244 & 1.42 & 0.854 & 2.380 \\
\hline Rural (ref) & $47(29.6)$ & $112(70.4)$ & 159 & & & \\
\hline \multicolumn{7}{|l|}{$\begin{array}{l}\text { Wealth as perceived by } \\
\text { household }\end{array}$} \\
\hline High & $8(50)$ & $8(50)$ & 16 & 2.19 & 0.554 & 8.654 \\
\hline Medium & $126(39)$ & $197(61)$ & 323 & $2.44^{*}$ & 1.192 & 4.978 \\
\hline Low (ref) & $13(21)$ & $49(79)$ & 62 & & & \\
\hline \multicolumn{7}{|l|}{$\begin{array}{l}\text { Exposure to any pro-FGM/C } \\
\text { campaign, information or } \\
\text { materials? }\end{array}$} \\
\hline No & $103(40.9)$ & $149(59.1)$ & 252 & $1.99^{*}$ & 1.203 & 3.291 \\
\hline Yes (ref) & $44(29.1)$ & 107 (70.9) & 151 & & & \\
\hline \multicolumn{7}{|l|}{$\begin{array}{l}\text { Exposure to any anti-FGM/C } \\
\text { campaign, information or } \\
\text { materials? }\end{array}$} \\
\hline No & $19(18.4)$ & $84(81.6)$ & 103 & $0.38^{*}$ & 0.173 & 0.834 \\
\hline Yes (ref) & $128(42.7)$ & 172 (57.3) & 300 & & & \\
\hline
\end{tabular}




\begin{tabular}{|c|c|c|c|c|c|c|}
\hline \multirow{3}{*}{ Predictors } & \multicolumn{2}{|c|}{ Decision } & \multirow{3}{*}{$\begin{array}{c}\text { Row } \\
\mathrm{n}\end{array}$} & \multirow{3}{*}{ OR $_{\text {adj }}$} & \multicolumn{2}{|c|}{$95 \%$ C.I of OR } \\
\hline & $\begin{array}{l}\text { Not to } \\
\text { circumcise } \\
(\%)\end{array}$ & $\begin{array}{l}\text { To } \\
\text { circumcise } \\
(\%)\end{array}$ & & & Lower & Upper \\
\hline & $n=147$ & $n=256$ & & & & \\
\hline \multicolumn{7}{|c|}{$\begin{array}{l}\text { Exposure to any anti- or pro- } \\
\text { FGM campaign, information } \\
\text { or materials? }\end{array}$} \\
\hline No & $12(22.6)$ & $41(77.4)$ & 53 & 0.93 & 0.313 & 2.746 \\
\hline Yes (ref) & $135(38.6)$ & $215(61.4)$ & 350 & & & \\
\hline \multicolumn{7}{|l|}{${ }^{*} p<0.05$} \\
\hline $\mathrm{OR}_{\mathrm{adj}}=\mathrm{Adju}$ & eference ca & & & & & \\
\hline
\end{tabular}

\section{Deciding on the type of cut}

As indicated earlier, with some of the shifts taking place on the ways people view and practise FGM/C, what is being decided is often not just whether to cut or not, but what type of cut should be performed. The importance of the type of cut is reflected by the time when the decision was made. Forty-two percent of survey respondents stated that they decided on the type of cut at the same time the decision to cut the girl was made (Figure 5). Twenty-one percent made the decision sometime after deciding to cut their daughter and a further 10 percent did so when preparing for the circumcision event. About 4 percent made the decision when the girl was undergoing the cut.

Figure 5. Timing of the decision on the type of cut.

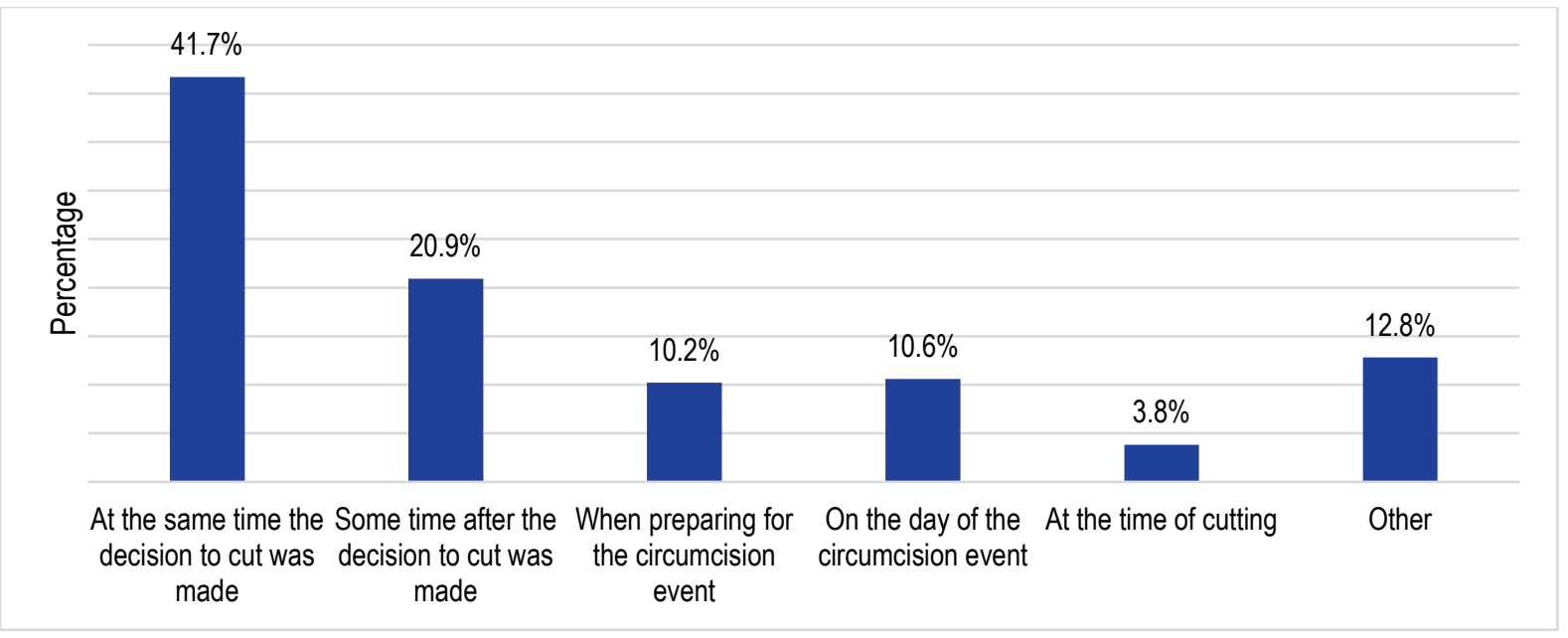

As shown in Table 13, several people in the immediate and extended families, as well as nonfamily members were involved in the decision about the type of cut. Seventy percent of respondents who reported that the decision was to circumcise the girl noted that mothers were involved in the decision on the type of cut. A substantial proportion of respondents also noted that the girl's father (21 percent), maternal grandmother ( 23 percent) and paternal grandfather (31 percent) were also involved. In 11 percent of the cases, the midwife or person who performed the procedure was also involved. 
Table 7. Persons involved in deciding the type of circumcision $(n=229)$.

\begin{tabular}{lcc}
\hline Person & $\mathbf{n}$ & \% \\
\hline Mother & 161 & 70 \\
Paternal grandmother & 71 & 31 \\
Maternal grandmother & 53 & 23 \\
Father & 48 & 21 \\
Midwife/person performed the procedure & 24 & 11 \\
Aunt & 20 & 9 \\
Don't know & 7 & 3 \\
Uncle & 5 & 2 \\
Sister & 3 & 1 \\
Friends or neighbours & 3 & 1 \\
\hline Multiple responses allowed & &
\end{tabular}

As shown in Table 14, over half of the respondents reported that the reason for the type of cut was that it was less severe, while 10 percent reported that the reason for the type of cut was that it was not harmful. Twenty-seven percent reported that the FGM/C type was religiously recommended, while 17 percent stated it was recommended by a health professional.

Table 8. Justifications for the decision on the type of circumcision $(n=229)$.

\begin{tabular}{lcc}
\hline Justification/criterion & $\mathbf{n}$ & \% \\
\hline Less severe & 117 & 51 \\
Religiously recommended type & 61 & 27 \\
Don't know & 43 & 19 \\
Recommended by health professional & 39 & 17 \\
Other & 31 & 14 \\
Not harmful & 24 & 10 \\
We wanted to have something symbolic & 10 & 4
\end{tabular}

Narratives from the qualitative interviews indicate that many people have shifted to the so-called "sunna" type, which was perceived as less severe, but at the same time serves the purpose of "reducing the sexual desire of the girls". Although only four states, including Gedaref, have an antiFGM/C law, according to some of the participants, the shift to the "sunna" cut, even in Khartoum, which lacks a law, may have been driven by fears about a largely perceived illegality of FGM/C. These views are illustrated in the following quotations: 
"Now people just do this simple 'sunna' type and they do it secretly because they are frightened of doing something illegal."

\author{
Man, FGD, Khartoum
}

"In the 'sunna' type they just take very little of the excess to reduce the sexual desire of the girl; all other things are left intact."

Man, FGD, Khartoum

"We think that the midwife simply does what she needs to do, but the trained midwives usually take very little and they do not sew women closed."

Man, FGD, Khartoum

"When women discuss female circumcision, here they say: they will not abandon the 'sunna' type, they say, 'we cannot leave our daughter ghuluf (uncircumcised)'."'

Woman, FGD, Gedaref

\title{
Men and FGM/C decisions
}

Both the survey and the qualitative interviews revealed the different roles that men play in $\mathrm{FGM} / \mathrm{C}$ discussions and decisions. Even when they were not directly and visibly involved, men were considered to influence the final decision. In line with the survey results, some qualitative interview participants noted that men were particularly involved in situations where they were opposed to the practice. These views are illustrated in the following quotes:

"Men often engage in female circumcisions talks when they oppose the practice and want to make sure it never happens to their daughter."

Woman, FGD, Gedaref

"Some men who oppose FGM/C talk with their wives to convince them not to do it. Some men who are strongly against it threaten their wives that they will divorce them if they do it."

Female community leader, Khartoum

"The final decision is for the father, as he is the head of the family and responsible for the wellbeing of the family."

Woman, FGD, Gedaref

Other participants noted that some men support the practice, and even fund it, but prefer not to get closely involved in the preparations and performance of the procedure. Given their role as protectors, providers and heads of household, men were considered by some to be the ultimate decision maker. These views are illustrated in the following quotations:

"There was a woman that I know, she said to her husband, 'Your mother said that we should circumcise our daughter.' He responded, 'What do you want from me?' She responded, 'cloths and a few other things.' He provided all these things and travelled and never attended the circumcision event."

Woman, FGD, Khartoum

"Men always participate in (FGM/C) as there are risks and things may go wrong. They also have to provide the funds for the procedure and its associated costs... Those who support the practice, would say do not listen to those women (activists) who ask you not to 
circumcise your daughters, as they, themselves are circumcised and you yourself are also circumcised and nothing happened to any of you."

\section{Woman FGD, Khartoum}

"The father is the one who always makes the final decision because he is the one in control, the head of the family, the owner of the house and the one with the strong management."

Woman, FGD, Khartoum

"The father is the one with the final decision because he is the one in charge of all the family affairs."

\section{Female community leader, Khartoum}

Although men were described as the ultimate decision makers, some participants reported that men are also influenced by others, including women in the family. As one female community leader explained, a man's mother and sister could also influence his decision. She stated:

"If the mother and sisters of the husband support FGM/C, they can influence his decision by talking to him as women about the advantages of circumcision. They can also scare him by telling him stories that the daughter of so and so was returned back to her parents' home from her honeymoon because her husband discovered that she was not circumcised."

Female community leader, Khartoum

Some men noted that FGM/C was driven by women's incorrect assumption that men wanted women to undergo FGM/C. As highlighted in an FGD among men in Khartoum, most married men and young boys preferred uncircumcised partners, who were reportedly more sexually responsive. One of the men in this FGD noted, "Women insist on this circumcision thing and they think that we men want it. If you ask most married men and most young men they will tell you that they prefer uncircumcised girls, because the circumcised are cold and not responsive.'

Men, especially young men, therefore seem to hold contradictory positions on FGM/C. The findings from the survey and qualitative interview narratives suggest that uncut girls are desirable because they are perceived as sexually responsive. However, at the same time, these girls are feared because their intact sexual drive and desires are viewed as uncontrollable and hence risky or dangerous. For some, these contradictory views meant that some young men preferred having their sisters circumcised but expressed their desire to have an uncut wife. These views are highlighted in the following quotes from young men who participated in FGDs:

"Some fear that a woman with high electric voltages (uncut) may have excessive sexual drive and their husband may not be able to satisfy them... this can be a problem."

$$
\text { Young man, FGD, Khartoum }
$$

"Her sexual satisfaction is distant even when married, she cannot easily feel sexual satisfaction with her husband... she always seeks more. This may lead her to go astray."

Young man, FGD, Khartoum

"Of course, it is better to have a wife with full battery as you will enjoy life with her."

Young man, FGD, Khartoum 
"The uncircumcised is also called the one with high voltage (hot)... you may not want this for your sister, as it can be dangerous, but it is nice to have such a wife...circumcised women can be left with no sexual desire at all."

Young man, FGD, Khartoum

\section{Discussion}

The household survey and qualitative interview findings indicate that $F G M / C$ is an issue that involves discussions among various members of the nuclear and extended family, as well as nonfamily members. Discussions do not only focus on whether girls in the family should undergo the cut, but also centre on the timing and type of cut. Household decisions about FGM/C are made following discussions that occur over time. Further, although there are shifts in people's views and attitudes, as well as the type of cut, FGM/C is still widely practised in the two study communities because of its perceived advantages. In particular, FGM/C is viewed as a means to 'protect' girls and young women-primarily by limiting their sexual desire. Findings suggest that views that shape, inform and sustain gender power relations are so internalised among women that many reproduce the power relations embedded in it. The social construction of girls as physically weak and incapable of protecting themselves is therefore a key driver of FGM/C. It is associated with strongly held misconceptions about women's (in)capabilities and the need for families to control and regulate women's behaviour, in particular, their sexual behaviour. Relatedly, getting married is extremely important for girls and women and remaining a virgin until marriage is believed to maximise marriage chances and ensure the sustainability of the marriage. In all cases, FGM/C views and practices sustain and consolidate gendered power relations that safeguard male dominance and female subordination.

Views that FGM/C is a sociocultural tradition or religious duty are also directly linked to the view that FGM/C is a practice necessary for reducing women's sexual desire, especially for unmarried women and girls. Social norms and religious teachings are understood in terms of entrusting parents and other family members to ensure women's and girls' chastity and fidelity, which are regarded as sacred and important for enhancing marriageability and the stability of marriage and ensuring family honour. Thus, religious and sociocultural justifications for the continuation of FGM/C may be more complex than commonly perceived. The justifications may, ultimately, reflect communities' needs to control women's sexual desires in highly patriarchal systems that view women's sexual desire as 'excessive' and as something that must be checked, reduced and controlled. The dominant gendered social norms that depict women as emotional and socially and psychologically weak, and hence incapable of protecting themselves, strengthen the dominant portrayal and justification of FGM/C as a form of 'protection' by the family and the community.

While participants were aware about the negative health consequences of FGM/C, this awareness does not seem to lead to abandonment. Instead, knowledge of the harms was noted to contribute to the medicalisation of the practice and a noticeable shift from the 'severe' pharaonic to the "sunna" cut, which was perceived to be 'less harmful or 'not harmful'. Although not frequently perceived as a religious duty, the religious connotations in the use of the term "sunna" (meaning Prophetic traditions in Islam) may play an important function in disguising the main intention behind the practice, which is the need to control women's sexual behaviour.

Contrary to commonly held views in Sudan, that often blame women for the continuation of $F G M / C$ (e.g. MICS, 2014), the study findings show that men within and outside the nuclear family are involved in FGM/C decision-making. Fathers, in particular, were reported to be involved in deciding whether their daughter would be cut, in paying for associated expenses, and in some cases, were the final decision maker. Similar to findings from a study in Senegal and The Gambia (UNDP/ 
UNFPA/ WHO/World Bank 2010) and a study in Sudan (Almroth et al. 2001), we found that fathers who were opposed to FGM/C were more likely to be involved in FGM/C related discussions. In other cases, men were reported to be less involved in the process although they retained the sociopolitical power to veto any decision that they did not fully support. These findings underscore the need to involve men in FGM/C abandonment programmes.

Participants noted that a broad network of individuals within and beyond the nuclear and extended family influenced their views and attitudes towards FGM/C. Contrary to widely held views about the power of influence of grandmothers in African society (e.g. Aubel 2011), the study findings indicate that mothers may be more influential than grandparents in decisions around $\mathrm{FGM} / \mathrm{C}$. Further, maternal and paternal grandmothers were more likely to be listed as influential decision makers in cases whether the final decision was to cut the girl and less so in cases where the decision was not to cut the girl. Thus, similar to findings by Almroth et al (2001) in their study in Gezira (Sudan), the results of this study suggest that there may be a significant shift in decisionmaking of $\mathrm{FGM} / \mathrm{C}$ with parents who question the value of $\mathrm{FGM} / \mathrm{C}$, either collectively or separately, making the final decision not to cut their daughter.

Mothers' and fathers' personal experiences with FGM/C were associated with the final decision to either cut girls or not. Specifically, a decision not to cut a daughter was more likely when the mother herself had not been cut, which also suggests that she was married to a man who was willing to marry an uncut woman. This result suggests that while the views of others are often important, personal experiences may also shape parents' decisions.

Men, especially young men, seem to have a peculiar or contradictory position on FGM/C. Study findings suggest that uncut girls are both desired and feared. Desired because they are perceived to be more sexual responsive as wives and feared because their intact sexual drive and desires are viewed as excessive and uncontrollable and, hence, damaging to family honour. One result of this contradictory view was that many young men were supportive of $\mathrm{FGM} / \mathrm{C}$ for their sisters while expressing their desire to marry an uncut girl.

We found that respondents who lived in Gedaref State were approximately twice as likely to decide not to circumcise their girl as those who live in Khartoum State. As noted earlier, Gedaref, unlike Khartoum, has a law against FGM/C. Thus, it is plausible that families in the former state may be more likely to choose not to circumcise their daughters in compliance with the law.

\section{Limitations}

The following are the main limitations of this study, which addressed a sensitive and complex issue within a conservative context. First, data were collected in only two states (Khartoum and Gedaref) out of the 18 states in the country. Although these states were carefully selected to provide a wide spectrum of the various diversities of economic and sociocultural factors and level of intervention and current prevalence rates, these states do not provide enough grounds for the generalisation of the study results to the rest of the country.

Second, the high number of female survey respondents may reflect the fact that the survey was conducted during the day when many men are at work. This was despite our efforts to work on weekends and in the late afternoon hours. However, for the qualitative component we purposively interviewed roughly equal numbers of men and women in each area.

Third, during the household survey, the head of the household had a choice to respond to the survey or to nominate the person who would complete the questionnaire on behalf of the household. While this approach might have introduced bias if those nominated to participate were 
more likely to hold a particular view, this approach was necessary given the sensitivity of the topic and the sociocultural context in which the research was conducted. Further, we were unable to request that other members of the household leave the room when the survey was administered. Nevertheless, we were mindful of the potential impact of having others present in the room and recorded this information. We are confident that the environment/context within which the survey was conducted had limited negative impact on the results of the study given the similarity in findings in the quantitative and qualitative components.

\section{Conclusion}

Within the current context of shifting views and attitudes towards FGM/C in Sudan, decisions made by families on $\mathrm{FGM} / \mathrm{C}$ are often a product of a lengthy and complex process of deliberations that involves many people within and beyond the nuclear and extended family. Although parents are often the final decision makers, they do not act in isolation but are influenced by dominant social norms and by other family members who are, in turn, also influenced by other people and norms. Members of the extended family, especially the grandmothers of the girl, tend to have greater degree of influence, mainly because of the nature of their relationship to the parents of the girls and the general influence they have on various aspects of their lives. Our findings also underscore the important role that men, particularly fathers, play in decision-making and highlight the need to involve men in anti-FGM/C programmes.

Our findings suggest that the widespread support and practise of FGM/C in the research area is perpetuated and sustained by deeply rooted social norms associated with gender power relations that control women as subordinate and undermine their rights. The norms are justified by the supposed need to 'protect' women and girls from their perceived excessive and dangerous 'sexual desire'. Such gender views are often projected as social norms and cultural values or religious beliefs.

\section{Programmatic, Research and Policy Implications}

\section{Programmatic Implications}

- The observed increase in the medicalisation of FGM/C and the "sunna" cut are both a threat and an opportunity for full abandonment efforts. These shifts may be an opportunity for further shifts and changes towards the abandonment of all forms of FGM/C. The involvement of medical cadres may also provide a chance to influence the spread of the practice through health regulations or legal reforms. At the same time, the belief that the "sunna" cut performed by trained medical staff addresses the harms arising from FGM/C may pose a huge challenge for abandonment efforts. FGM/C plans and programmes at all levels must therefore respond to the medicalisation of FGM/C and the shift to "sunna" cutting.

- The study findings underscore the need for interventions that address gendered social norms that support the regulation of women's sexuality and sexual behaviour. Programmes should incorporate sexual and reproductive health education targeted towards men and women of different ages.

- Important moments in the decision-making process are the time (and age) when deliberations on $\mathrm{FGM} / \mathrm{C}$ are initiated and the time of the year/season (and age) when girls are typically circumcised. These key moments present windows for intensive campaigns and programmatic interventions. 
- Men are directly and indirectly involved in FGM/C decisions. Men-both young and old-must therefore be targeted in FGM/C programmes. Further, their views and positions on FGM/C must be understood and integrated in efforts to address abandonment.

\section{Research Implications}

Study findings highlight several important research gaps:

- While many participants who still practise FGM/C claim that girls undergo the "sunna" cut, little is known about what the "sunna" cut means, its religious underpinnings, and the implications of this shift on efforts to abandon all types of FGM/C. Further research on this shift is warranted.

- Gender and social norms about women's sexual behaviour and sexuality are significant, but not well understood. Further research is needed to how these norms intersect with religious norms to sustain $\mathrm{FGM} / \mathrm{C}$.

- Increased migration and access to mass media may influence people's reference groups and social networks. Further research is needed to understand the nature of social networks in increasingly complex contexts.

- Fathers were noted to be very influential especially in instances where they were opposed to having their daughters circumcised. Similarly, some young men reported contradictory views about FGM/C noting their willingness to marry uncut women, while supporting FGM/C for their own sisters. Further research is needed to understand men's views and attitudes towards FGM/C. A better understanding of their views and attitudes may inform the development of programmes targeted to men.

\section{Policy Implications}

- Study findings suggest that legal restrictions may promote the abandonment of FGM/C or drive shifts in the practice. These results suggest the need for investments in research to understand how laws can be strengthened to promote the abandonment of all forms of FGM/C. 


\section{References}

Abathun, A. D., Gele, A. A., \& Sundby, J. (2017). Attitude towards the practice of female genital cutting among school boys and girls in Somali and Harari Regions, eastern Ethiopia. Obstetrics and Gynecology International. https://doi.org/10.1155/2017/1567368

Ahmed, S., Al Hebshi, S., \& Nylund, B. V. (2009). Sudan: An in-depth analysis of the social dynamics of abandonment of FGM/C. Special Series on Social Norms and Harmful Practices, Innocenti Working Paper No. 2009-08. Florence, UNICEF Innocenti Research Centre.

Allam, M. F. A., de Irala-Estevez, J., Navajas, R. F. C., del Castillo, A. S., Hoashi, J. S., Pankovich, M. B., \& Liceaga, J. R. (1999). Students' knowledge of and attitudes about female circumcision in Egypt. New England Journal of Medicine, 341(20), 1552-1553.

Almroth, L., Almroth-Berggren, V., Hassanein, O. M., El Hadi, N., Al-Said, S. S., Hasan, S. S., Lithell, U.B., Bergström, S. (2001). A community based study on the change of practice of female genital mutilation in a Sudanese village. International Journal of Gynaecology and Obstetrics, 74(2), 179-85. https://doi.org/10.1016/S0020-7292(01)00392-7

Aubel, J. (2011). The role and influence of grandmothers on child nutrition: culturally designated advisors and caregivers. Maternal \& Child Nutrition, 8(1), 19-35.

Ballenger, T. (2008). Female genital mutilation: legal and non-legal approaches to eradication. Journal of Law \& Social Challenges, 9, 84.

Barstow, D. G. (1999) Female genital mutilation: the penultimate gender abuse. Child Abuse, 23(5), 501-510.

Begum, F. S. (2016). Gender equality and women's empowerment: suggested strategies for the 7th five year plan. General Economics Division: Planning Commission of Government Bangladesh. Retrieved from http://www.plancomm.gov.bd/wpcontent/uploads/2015/02/16_Gender-Equality-and-Womens-Empowerment.pdf

Berg, R. C., \& Denison, E. (2013). A tradition in transition: factors perpetuating and hindering the continuance of female genital mutilation/cutting (FGM/C) summarized in a systematic review. Health Care for Women International, 34 (10), 837-859, DOI: 10.1080/07399332.2012.721417

Berkowitz, A. D. (2003). Applications of social norms theory to other health and social justice issues. In H. W. Perkins (Ed.), The social norms approach to preventing school and college age substance abuse: A handbook for educators, counselors, and clinicians (pp, 259-279). San Francisco: Jossey-Bass.

Bicchieri, C. 2005. The grammar of society: The nature and dynamics of social norms. Cambridge, UK: Cambridge University Press

Black, J. A., \& Debelle, G. D. (1995). Female genital mutilation in Britain. BMJ: British Medical Journal, 310(6994), 1590. https://doi.org/10.1136/bmj.310.6994.1590.

Broussard, P. A. (2008). Female genital mutilation: Exploring strategies for ending ritualized torture; shaming, blaming, and utilizing the convention against torture. Duke Journal of Gender Law \& Policy, 15, 19-48.

Brown, K., Beecham, D., \& Barrett, H. (2013). The applicability of behaviour change in intervention programmes targeted at ending female genital mutilation in the EU: integrating social 
cognitive and community level approaches. Obstetrics and Gynecology International, 2013. http://dx.doi.org/10.1155/2013/324362.

Central Bureau of Statistics (CBS), and UNICEF Sudan. (2016). Multiple Indicator Cluster Survey 2014 of Sudan, Final Report. Khartoum, Sudan: UNICEF and CBS.

Central Bureau of Statistics (CBS). (2009). Fifth Population Census, Khartoum

Central Bureau of Statistics. (ND). Social and demographic statistics. Retrieved from https://tinyurl.com/yc6ygfc5

Cislaghi, B., \& Heise, L. (2018). Using social norms theory for health promotion in low-income countries. Health Promotion International. https://doi.org/10.1093/heapro/day017

Clarence-Smith, W. (2012). Female circumcision in Southeast Asia since the coming of Islam. In: C. Raghavan and J. P. Levine (eds.), Self-determination and women's rights in Muslim societies (pp. 124-146). Waltham, MA: Brandeis University Press.

Cohen, S. J. D. (2005). Why aren't Jewish women circumcised? Gender and covenant in Judaism. Berkeley: University of California Press.

Daniel, W. W. (1999). Biostatistics: A foundation for analysis in the health sciences. Hoboken: Wiley.

Davies, P. (1992) On relapse: recidivism or rational response? In P Aggelton, P. Davies, \& G. Hart (Eds). AIDS: Rights, Risk and Reason (pp. 133-141). Washington D.C: The Falmer Press.

Dirie, M. A., \& Lindmark, G. (1991). A hospital study of the complications of female circumcision. Tropical Doctor, 21(4), 146-148.

Efferson, C., Vogt, S., Elhadi, A., Ahmed, H. E. F., \& Fehr, E. (2015). Female genital cutting is not a social coordination norm. Science, 349(6255), 1446-1447.

Eric, A. (2000) Law and Social Norms. Cambridge, MA: Harvard Univ. Press.

Gamal Eldin, A. (2014) Mapping of FGM actors in six states in Sudan. A report for GRACE, for a study funded by UNFPA

Gamal Eldin, A. and Hussein, F. (2014) Discussing and deciding on female genital mutilation/cutting (FGM/C): Decision making processes within families of different backgrounds, experiences and positions. Research Report. Khartoum: GRACe, Ahfad University for Women.

Glanz, K., Rimer, B. K., \& Viswanath, K. (Eds.). (2008). Health behavior and health education: theory, research, and practice. John Wiley \& Sons.

Gordon, D. (1991). Female circumcision and genital operations in Egypt and the Sudan: A dilemma for medical anthropology. Medical Anthropology Quarterly, 5(1), 3-14.

Gruenbaum, E. (2001). The female circumcision controversy: an anthropological perspective. Philadephia: University of Pennsylvania Press.

Gruenbaum, E. (2005). Sociocultural dynamics of female genital cutting: Research findings, gaps and directions. Culture, Health \& Sexuality 7 (5):429-41

Herieka, E., \& Dhar, J. (2003). Female genital mutilation in the Sudan: survey of the attitude of Khartoum university students towards this practice. Sexually Transmitted Infections, 79(3), 220-223. 
Hernlund, Y., \& Shell-Duncan, B. (2007). Transcultural positions: negotiating rights and culture. In Y. Hernlund \& B. Shell-Duncan (Eds.) Transcultural bodies: Female genital cutting in global context (pp. 1-45). New Brunswick, New Jersey, and London: Rutgers University Press.

Janis, I. L., \& Mann, L. (1977). Decision making: A psychological analysis of conflict, choice, and commitment. New York: Free Press.

Kaplan, A., Cham, B., Njie, L. A., Seixas, A., Blanco, S., \& Utzet, M. (2013). Female genital mutilation/cutting: the secret world of women as seen by men. Obstetrics and gynecology international, 2013. http://dx.doi.org/10.1155/2013/643780.

Ladjali, M., Rattray, T. W., \& Walder, R. J. (1993). Female genital mutilation. British Medical Journal, 307(6902), 460-461.

Lewnes, A. (Ed.). (2005). Changing a harmful social convention: female genital mutilation/cutting. UNICEF Innocenti Research Centre.

Lockhat, H. (2004). Female genital mutilation: treating the tears. Oxfordshire: Libri Publishing.

Mackie, G. (2017) Female genital cutting is a social norm of coordination, Reply to Efferson et al. (2015), Science, 349(6235):1446-1447 \& Supplementary Materials, December 2017.

Mackie, G. (1996). Ending footbinding and infibulation: A convention account. American Sociological Review, 61(6), 999-1017.

Mackie, G. (2000). Female genital cutting: the beginning of the end. In B. Shell-Duncan \& Y. Hernlund (Eds.) Female" circumcision" in Africa: Culture, Controversy, and Change (pp. 253-282). Boulder and London: Lynne Reinner Publishers, Inc.

Mackie, G., \& LeJeune, J. (2009). Social dynamics of abandonment of harmful practices: A new look at the theory. Special Series on Social Norms and Harmful Practices, Innocenti Working Paper, 6, 2009-06.

Mackie, G., Moneti, F., Shakya, H. \& Denny, E. (2012). What are social norms? How are they measured. UNICEF Working Paper. San Diego and New York: University of California at San Diego and UNICEF.

Simonet, M. J. (2005) "FMG: Sunna oder Verbrechen aus Tradition," stopFMG.net, Vienna.

Mumtaz, Z., \& Salway, S. (2009). Understanding gendered influences on women's reproductive health in Pakistan: moving beyond the autonomy paradigm. Social Science \& Medicine, 68(7), 1349-1356.

Nichols, S. (2004). Sentimental rules: On the natural foundations of moral judgment. Oxford: Oxford University Press.

Niemiec, T., \& Rogowska-Szadkowska, D. (2009). Female circumcision-a new issue for gynecologists practicing in the EU countries? Ginekologia Polska, 80(2), 118-123.

Obermeyer, C. M. (1999). Female genital surgeries: the known, the unknown, and the unknowable. Medical Anthropology Quarterly, 13(1), 79-106.

Odimegwu, C. O., and C. N. Okemgbo. 2000. Female circumcision and sexual activity: Any relationship? UNILAG Sociological Review 1:159-76.

Rahman, A., \& Toubia, N. (2000) Female genital mutilation: a guide to laws and policies worldwide. London and New York: Zed Books.

Rogers, E. M. (2003). The diffusion of innovation ( $5^{\text {th }}$ edition). New York: Simon \& Schuster, Inc. 
Saeed, I. E., Weng, H.-Y., Mohamed, K. H., \& Mohammed, S. I. (2014). Cancer incidence in Khartoum, Sudan: first results from the Cancer Registry, 2009-2010. Cancer Medicine, 3(4), 1075-1084. http://doi.org/10.1002/cam4.254

Sami, I. R. (1986). Female circumcision with special reference to the Sudan. Annals of Tropical Paediatrics, 6(2), 99-115.

Shandall, A. A. (1967). Circumcision and infibulation of females: a general consideration of the problem and a clinical study of the complications in Sudanese women. Sudan Medical Journal, 5(4), 178-212.

Shell-Duncan, B. \& R. E. B. Johansen. (2010). Dynamics of decision-making and change in the practice of female genital mutilation in the Gambia and Senegal. Geneva: World Health Organization. Social Science Policy Brief. Retrieved from http://www.who.int/reproductivehealth/publications/fgm/rhr_hrp_10_16/en/

Shell-Duncan, B. (2002). Conceptual and methodological issues in studying sociocultural determinants of female genital cutting. Presented at the Conference to Advance Research on Female Genital Cutting, Bellagio, Italy, May 2012.

Shell-Duncan, B. (2008). From health to human rights: Female genital cutting and the politics of intervention. American Anthropologist, 110(2), 225-236.

Shell-Duncan, B., \& Hernlund, Y. (2006). Are there "stages of change" in the practice of female genital cutting? Qualitative research finding from Senegal and the Gambia. African Journal of Reproductive Health, 10(2), 57-71.

Shell-Duncan, B., \& Hernlund, Y. (Eds.). (2000). Female" circumcision" in Africa: culture, controversy, and change. Boulder and London: Lynne Rienner Publishers.

Shell-Duncan, B., Hernlund, Y., Wander, K., \& Moreau, A. (2010). Contingency and change in the practice of female genital cutting: dynamics of decision making in Senegambia. Summary Report. Retrieved from https://goo.gl/zfzbPt.

Shell-Duncan, B., Obiero, W. O., \& Muruli, L. A. (2000). Women without choices: the debate over medicalization of female genital cutting and its impact on a northern Kenyan community. In B. Shell-Duncan \& Y. Hernlund (Eds.) Female" circumcision" in Africa: Culture, Controversy, and Change (pp. 109-128). Boulder and London: Lynne Reinner Publishers, Inc.

Shell-Duncan, B., Wander, K., Hernlund, Y., \& Moreau, A. (2011). Dynamics of change in the practice of female genital cutting in Senegambia: testing predictions of social convention theory. Social Science \& Medicine, 73(8), 1275-1283.

Shetty, P. (2014). Slow progress in ending female genital mutilation. Bulletin of the World Health Organization, 92(1), 6-7.

SHHS (2000) Sudan Household and Health Survey, Government of Sudan.

SHHS (2006) Sudan Household and Health Survey, Government of Sudan.

SHHS (2010) Sudan Household and Health Survey, Government of Sudan.

Stein, K., Hindin, M. J., Chou, D., \& Say, L. (2017). Prioritizing and synthesizing evidence to improve the health care of girls and women living with female genital mutilation: An overview of the process. International Journal of Gynecology \& Obstetrics, 136(S1), 3-12. 
Tiam, M. (2015). Female genital mutilation/cutting (FGM/C) and child marriage in Sudan - are there any changes taking place? An in- depth analysis using Multiple Indicators Cluster Surveys (MICS) and Sudanese Household and Health Surveys (SHHSs). Sudan: UNICEF 2016

Toubia, N. (1994). Female circumcision as a public health issue. New England Journal of Medicine, 331(11), 712-716.

UNDP/UNFPA/WHO/World Bank (2010) Dynamics of decision-making and change in the practice of female genital mutilation in the Gambia and Senegal, Special Programme of Research, Development and Research Training in Human Reproduction, 2010,

UNICEF. (2016). Female genital mutilation/cutting: a global concern. New York: UNICEF.

United Nations Children's Fund (UNICEF). (2013). Female genital mutilation/cutting: A statistical overview and exploration of the dynamics of change. New York: UNICEF.

Wangila M. N. (2007). Female circumcision: The interplay of religion, culture, and gender in Kenya. Maryknoll, New York: Orbis Books.

Yoder, J. D. (2001). Making leadership work more effectively for women. Journal of Social Issues, 57(4), 815-828.

Young, H. P. (2007). Social Norms. Discussion Paper, Department of Economics, University of Oxford.

from https://www.economics.ox.ac.uk/materials/working papers/paper307.pdf 